University of Rhode Island

DigitalCommons@URI

Open Access Master's Theses

1993

\title{
A Comparison of War-Related Stressors to Other Stressors in 5th and 7th Grade Children
}

Elaine C. Lee

University of Rhode Island

Follow this and additional works at: https://digitalcommons.uri.edu/theses

\section{Recommended Citation}

Lee, Elaine C., "A Comparison of War-Related Stressors to Other Stressors in 5th and 7th Grade Children" (1993). Open Access Master's Theses. Paper 1698.

https://digitalcommons.uri.edu/theses/1698

This Thesis is brought to you for free and open access by DigitalCommons@URI. It has been accepted for inclusion in Open Access Master's Theses by an authorized administrator of DigitalCommons@URI. For more information, please contact digitalcommons@etal.uri.edu. 


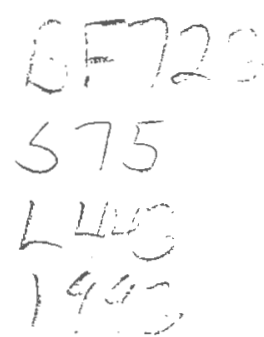

A COMPARISON OF WAR-RELATED STRESSORS

TO OTHER STRESSORS IN 5TH AND 7TH GRADE CHILDREN

BY

ELAINE C. LEE

A MASTER'S THESIS SUBMITTED IN PARTIAL FULFILLMENT OF THE REQUIREMENTS FOR THE DEGREE OF MASTER OF ARTS IN PSYCHOLOGY

$$
2964613
$$

UNIVERSITY OF RHODE ISLAND 


\section{Abstract}

Events in the Middle East and the war in the Persian Gulf gave impetus to a study to determine how stressful various life events are perceived by children. Research has shown that it is important, not only to understand how stress affects children from an adult's perspective, but also from a child's perspective. studies have shown that many events, both daily and major life experiences, can create stress in children. Previously identified stressrelated factors for children include feelings of isolation, family disruptions, learning and school difficulties, and financial concerns.

This research summarizes the results of a study that assessed stress in children, paying particular attention to stressors related to acts of war. Several questions were addressed: (a) Are there clusters or groupings of experiences perceived to be stressful by children? (b) Is war perceived as a distinctive stressor by children? (c) Are there group differences (grade and gender) in children's reports of perceived stressful experiences, particularly those questions related to war? (d) Did the involvement of a family member in the Persian Gulf crisis influence children's reports of war stressors?

Data were collected during the fall of 1991 from fifth and seventh grade children $(\mathrm{n}=842)$ in three Rhode Island school districts. Included on the questionnaire were items 
more typically associated with normal life experiences, as well as war-related items. A principal components analysis (PCA) determined that there were seven identifiable components accounting for $47 \%$ of variance. The component labeled War Issues represented 498 of the accounted for variance, however, contrasting the fact that it captured the highest amount of variance, this component was shown to have the lowest mean rating so could not be viewed as a stressor. Fifth graders reported higher levels of stress than seventh graders on five of the seven components. In addition, females reported significantly more stress than males if there were family members involvement in the Gulf War crisis.

The results pertain to the usefulness in planning future crisis intervention programs for school-age children. 
Acknowledgement

This acknowledgement gratefully recognizes the contributions of my thesis committee. I would especially like to thank Janet Kulberg, Ph.D., who supported me throughout the process of my completing this research project; W. Grant Willis, Ph.D., who strengthened my understanding of the importance of science-based research; Richard Sullivan, Ph.D., who provided positive comments and support; and to Jerry Cohen, Ph.D., for his statistical guidance. Also, I would like to acknowledge the important role played by Alexa Albert, Ph.D., who chaired my committee meetings.

Particular thanks go to Patricia Lemay who has provided unfailing support and humor during the unfolding of this research process; to Denise DeZolt, Ph.D., who offered continuous guidance; to Jim Arruda, particularly for his patience, availability and guidance during the analysis of my data. Finally, to my son, Marcus, who ran all my errands and helped organize my personal life so I could devote my time to this project and to my daughter, Avery, who has continuously supported my educational endeavors.

Special thanks also go to my classmates who have provided friendship, support, and assistance during the past three years. The final thanks goes to my long-time friend and secretary, Gloria Marshall, who once again has put the finishing touches on another of my projects. 


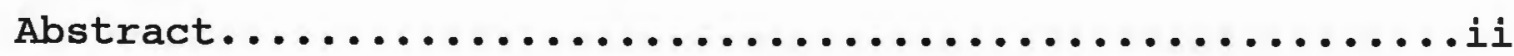

Acknowledgements........................... iv

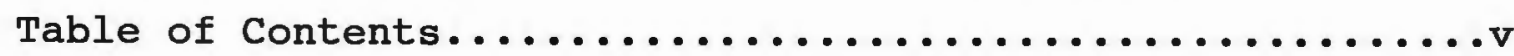

List of Tables.............................. vi

List of Figures..............................

List of Appendixes.................................

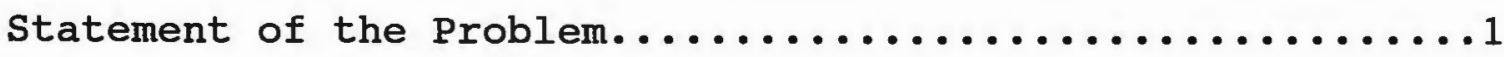

Background Theory and Research...................

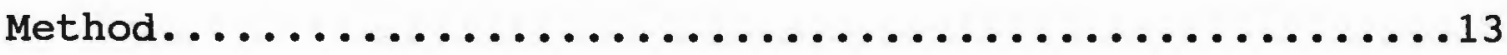

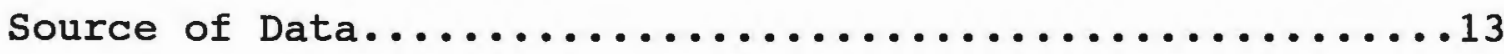

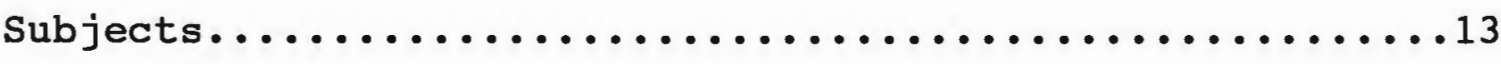

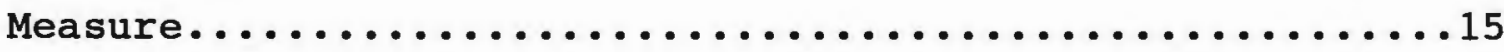

Procedures.................................

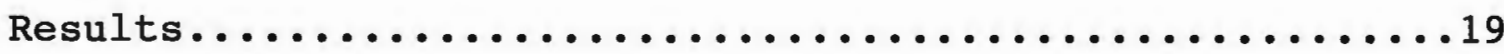

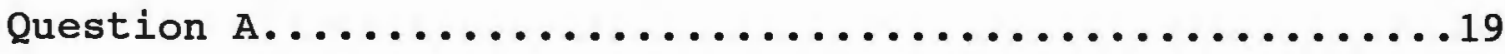

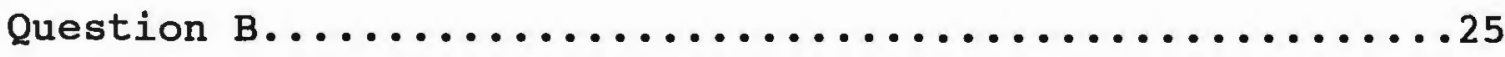

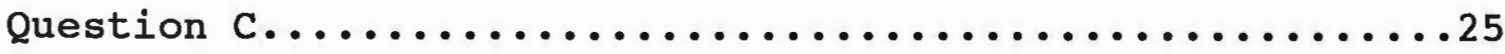

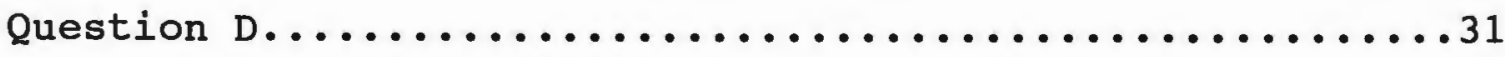

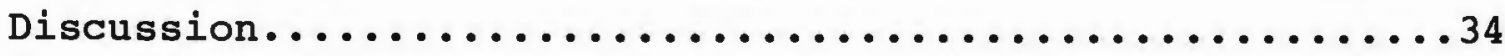

Appendix A, Questionnaire......................... 3

Appendix B, Teacher's Instructions................48

Appendix C, Additional Tables

Table 9, Means and Standard Deviations on Ratings on Items with Significant Factor Load.....50

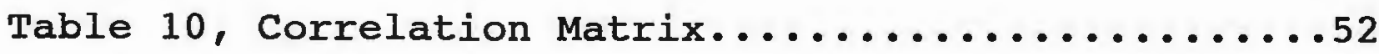

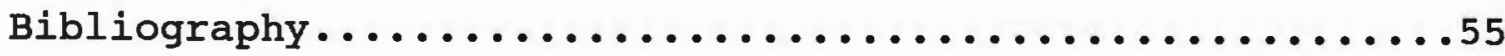


Table

Iist of Tables

1. Demographics of School Districts Used in Study.......14

2. Sample Description............................ 15

3. Oblique Rotated Principal Factor Loadings for

the Stress Self-Report Measure..............20

4. Means and Standard Deviations of Ratings on

Items Without Significant Factor Loadings.........23

5. Correlations Matrix for C1, C2, C3, C4, C5, C6, C7...24

6. Means and Standard Deviations on Components

$\mathrm{C} 1, \mathrm{C} 2, \mathrm{C} 3, \mathrm{C} 4, \mathrm{C} 5, \mathrm{C} 6, \mathrm{C} 7 \ldots \ldots \ldots \ldots \ldots \ldots \ldots \ldots \ldots \ldots$

7. Summary of Simple Effects Tests for Grade and Gender at $\mathrm{C} 1, \mathrm{C} 2, \mathrm{C} 3, \mathrm{C} 4, \mathrm{C} 5, \mathrm{C} 6, \mathrm{C} 7 \ldots \ldots \ldots \ldots . . . . .30$

8. Means and Standard Deviations of Involved and Non-involved Males and Females on War Issues (C1) ...32 


\section{List of Figures}

Figure

1. Mean stress level on components for grades

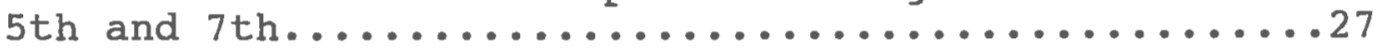

2. Mean stress level on components for males

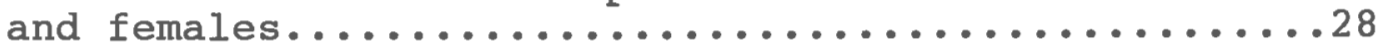

3. Gender by involvement interaction on war issues.....33 
List of Appendixes

Appendix Page

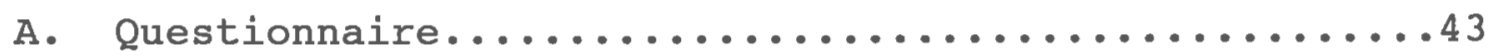

B. Teacher's Instructions.....................48

c. Additional Tables

Means and Standard Deviations of Ratings

on Items With Significant Factor Loadings........50

Correlation Matrix of Questionnaire Items........52 
A COMPARISON OF WAR-RELATED STRESSORS

TO OTHER STRESSORS IN 5TH AND 7TH GRADE CHILDREN

Introduction

Statement of the Problem

Activities in the Persian Gulf, the direct communication via television from war zones, and the constant descriptions of war torn areas, raised interest in how concerns related to war activities might be perceived by children in comparison to other stressors. The purpose of this project was to assess children's perceptions of stressors in general and those specifically related to the acts of war. Several questions were addressed: (1) Are there clusters or groupings of experiences perceived to be stressful by children? (2) Is war perceived as a distinctive stressor by children? (3) Are there group differences (grade and gender) in children's reports of perceived stressful experiences, particularly those experiences related to war? and (4) Did the involvement of a family member in the Persian Gulf crisis influence children's perceptions of war stressors?

\section{Background Theory and Research}

Definition of stress. To address these questions, it is important to examine the defining properties of stress and the types of events that are perceived as stressful for children. Although researchers have used similar sets of environmental characteristics to delineate stress, the overlap among these sets of characteristics has not prevented the emergence of varied definitions for stress. 
Rutter (1988) acknowledges that several perspectives can be used to define stress and that stress lacks any agreed-upon definition. Lazarus and Launier (1978) note that stress can be viewed as a stimulus, a response, or an interactional relationship. As an example of an interactional definition, a frequently-cited stress researcher, Selye (1982), defines stress as a disequilibrium in the psychological system caused by a severe stimulus event. Breznitz and Goldberger (1982) argue that the definition of stress adopted by a researcher should be based on the nature of the study. Honig (1986), reviewing studies of stress and coping in young children, argued that children's appraisal of stressors show marked individual differences in how children respond to potential stressors, and by implication, suggests that stress should be viewed from the perspective of the child.

There are several major theoretical perspectives used in stress research. The perspective that most closely fits the design of this study is a societal perspective. A societal perspective considers the environmental event as the major contributing factor in defining stress. In this theory there are two dimensions of environmental events considered important to stress (Magnussom, 1982). The first is the actual environmental event which includes the physical properties of the event. The second is the psychological experience of the event which includes the 
perceptions, cognitions, emotions, and reactions of the individual. To illustrate the difference between these two dimensions of stress, Honig (1986) recites the story of two small children who were in a car that developed engine trouble. One child was in tears over the concern that they would be unable to get the car fixed and, consequently, unable to get home. The second child followed the event with interest, expressed curiosity about how the problem would be solved and felt the entire experience was an adventure.

The perceived approach to defining stress, as described in this societal perspective, resembles the process-oriented model adopted by Lazarus and his colleagues. In the process-oriented model, stress is viewed as the outcome of the interaction between the demands of the environment and the individual's appraisal of the environmental event (Lazarus \& Launier, 1978). It is the appraisal of the environmental event that determines whether a situation is significant enough to trigger a stressful reaction. Thus, characteristics of the individual (i.e., child) interact with the characteristics of the environment to create a stress reaction. In the process-oriented model, the characteristics of the individual are important in determining whether the environmental event will be perceived as stressful. Lazarus, Delongis, Folkman, and Gruen (1985) discuss the problem of defining stress and 
conclude, "stress is an 'unclean' variable in that as a concept it depends on the interaction of two complex systems, the environment and the person." (p. 778).

For this study the societal perspective, specifically the process-oriented model, is used to define stress. Specifically, the focus is on children's perceptions or appraisal of environmental events. In particular, children's perceptions of how upsetting different events are to them is used to define stress.

Measurement of stress. Attempts have been made to measure stress in children by several approaches, including adults ratings of children's stress and children's own self report. The most common method for assessing stress in children has been adults' reports (Coddington, 1972; Karr \& Johnson, 1987). However, researchers have cited a number of methodical problems associated with this approach to assessing stress (Colton, 1985; Elwood, 1987; Yamamoto \& Felsenthal, 1982), and have suggested that adult reports are not always the best indicators of what children perceive as stressful. For example, Yamamoto and Felsenthal (1982) found that children's ratings of stress across cultures were more highly correlated than between adults and children within the same culture. In the study, the obtained coefficients were .91 between American and Japanese children, .85 between American and Filipino children, and .81 between the Filipino and Japanese children. In 
contrast, the correlation coefficient between American children and American professionals was .68. Because of these inconsistencies between adult and child ratings, Yamamoto and his colleagues set out to validate systems of children's ratings. They have shown that children can selfevaluate the amount of stress for different environmental events (Yamamoto, 1979; Yamamoto \& Byrnes, 1987; Yamamoto \& Davis, 1982). Several other stress measures using children's perceptions of stress also have been found to provide valid representations of children's stress (Colton, 1985; Elwood, 1987).

Empirical studies have shown that measures used to evaluate children's perception of stress have produced several different categories or types of stress for children. For example, in a study using fourth and eighth grade elementary school children's perception of stress, Colton (1985) identified seven factors or categories of children's stress. The categories identified were Isolation, Major Life Events, Family Disruptions, Cognitive Overload, Financial Concerns, Step-Families, and School Problems. In another study using Colton's scale with sixth grade children, Lemay (1993) identified six factors of children's perceived stress. Three were Major Life Events, School Problems and Step-Families, and were identical to three of Colton's findings. Three additional categories closely resembled Colton's factors of Isolation, Family 
Disruptions, and Cognitive Overload. Elwood's (1987) assessment of stress, in a study using fourth and seventh graders $(n=303)$, yielded two main categories of stressors for children (i.e., Major Life Events and Daily Hassles). Finally, a study of elementary, intermediate and high school students $(n=60)$ identified several types of stress present in children across the age groups (Omizo, Omizo \& Suzuki, 1988). The areas identified were Family-related Problems, School-related Problems, Social Relationships and Selfesteem issues.

To summarize, the research literature supports the existence of various types of stressful environmental events in the lives of children. There seems to be some agreement on groupings or classifications of perceived stressors, (i.e. Major Life Events, Daily Hassles, Isolation, StepFamilies, Family Disruptions and Cognitive Overload). Additionally, support is gained for the use of children's perceptions of stress (i.e., perceived environmental event) in researching stress. These groupings have also accounted for approximately $50 \%$ of the variance in scales used to assess stress in children.

War as a stressor. In addition to events in children's lives that already have been identified as potentially stressful, another area that warrants investigation is the possibility of war-related events as stressful for children. Myers-Walls and Fry-Miller (1984) found that children as 
young as six years of age suffer from fears, nightmares, and despair due to the possibility of nuclear destruction through war or accident.

Although research on the direct effects of war on children is limited, there is support that war and warrelated events are associated with stress in children. In a study on Lebanese children, Chimienti, Nasr, and Khalifeh (1989) found that children who witnessed the death of a family member, displacement of the family, destruction of their home or death were more likely to exhibit stressrelated behaviors (i.e., nervous, aggressive, regressive, and depressive behaviors than children who had not directly witnessed these war-related traumas, even though their nation was at war. Rosenheck (1986) did a similar study with children of World War II survivors. He found that the children of parents who experienced post-traumatic stress due to their involvement in the war also experienced long-term psychological trauma that was carried into adulthood. Empirical evidence also supports that the loss of a father in war presents severe problems for children, especially between the ages of two and ten. Kaffman and Elizur (1984) studied 24 normal children between the ages of one and ten whose fathers had been killed in the October 1973 war in Israel. They found that these children were traumatized to the point that they were hindered in their daily functioning and psychological help was considered 
imperative. Kaffman and Elizur concluded that the children's stress was probably due to a change in life style resulting from the death of the father.

Milgram and Milgram (1976) compared war-time and peacetime behaviors in fifth and sixth grade Israeli children $(n=85)$ four months prior to the Yom Kippur war and again while the war was still in progress. They found significant elevations in symptoms of stress (i.e., anxiety) for the majority of the children during war-time as compared to peace-time. However, there were no significant differences in levels of anxiety in children who had family members involved in the war compared to those children who had no immediate family members involved. In a study discussing stress and communication patterns in families ( $\mathrm{n}=118)$ during war-time and peace-time in Israel, Cohen and Dotan (1976) found that families reported significantly more stress and an increase in inter-familial communication in war-time than in peace-time. Also as in the Milgram and Milgram study, there were no significant differences in reported stress in those families that had a family member involved in the war as compared to those families who had no family member involved.

Clinical observations reported in literature support the influence of war and war-related events on the lives of children. In London during World War II many children were placed in nurseries in the country for safety purposes, and 
many of these children were the subjects of study by Anna Freud (1944), who directed one of the receiving centers. Quite often these children were separated from both parents; the father was serving in one of the armed forces and the mother was often in one of the major cities working for the war effort. According to Freud, the children who were separated from their mothers before the age of six months had relatively little trouble adjusting to new caretakers. However, children beyond the age of six months went through a severe grieving period. Many of these children, once adjusted to the absence of their mothers, refused to recognize the mother's presence when she returned. Fathers did not receive the same indifference upon their return, primarily because the child did not look upon the father as the person to satisfy its dependency needs (Freud, 1944). By the age of about five, the child began to have some understanding of why he/she had to be separated, however, there was a great deal of ambivalence when parental visits were made.

Freud also reported that the children often would keep their memories of frightening experiences to themselves for a period of six months to a year and, when they were ready to speak about the incidents, they did so in extensive detail. She stated that the children did not talk about the incidents until they had internally dealt with the feelings. Children did, however, use war games as a means of dealing 
with the bombing going on around them, if they experienced bombings in their lives. If the children were removed from the bombing scene before the age of two, they did not seem to incorporate war activity in their games even if they were separated from their mothers.

In addition to direct experience, there is also some literature that supports that indirect war-related experiences can affect the lives of children. Nagata (1990) studied the effects of cross-generational stress between Japanese interned during World War II and their children. The result showed that the children of interned Japanese Americans experienced an increase in stress (i.e., about their place in society in the American culture) due to the families' war-related experiences. Rosenheck's (1985) Case history of a ten-year old male child of a vietnam war veteran, revealed that the young boy exhibited numerous symptoms (i.e., guilt, anxiety, aggressiveness, and preoccupation with the events that were traumatic for the father) associated with post traumatic stress.

Finally, discussions of children's stress in the research literature note that war, whether directly or indirectly (i.e., through a family member involvement in war) experienced, is cited as a possible stressor for children (Coddington, 1972; Honig, 1986). There is not a great deal of literature that analyses the effects of war on children who are not directly involved in war. However, 
war, or the threat of war surrounds children in our society today. Studies have shown that children who have experienced direct involvement in war are experiencing more stress, (Chimienti, Nasr, \& Khalifeh 1989; Kaffman \& Elizur, 1984). However, the literature supports the concept that it is the loss of a family member, or a displacement of life style that appears to create elevations in stress levels, rather than the effects of war itself (Milgram \& Milgram, 1976; Cohen \& Dotan, 1976). In addition, the literature supports the concept that children who have a family member involved in war are not experiencing more stress than children who do not have family member involvement in the war, if the war is on distant shores and if no family members are killed or injured Kaffman and Elizur (1984). The literature does support, however, that children do experience fears about the threat of nuclear war, no matter where the war is happening, Myers-Walls and Fry-Miller $(1984)$.

Grade (age) and gender. Rutter (1988) notes that there are a number of personal qualities and characteristics of the individual (child) that are important in stress reactions. Two of the variables identified by Rutter are age and sex. Using Yamamoto's scale, Yamamoto and Davis (1982) reported that older children experienced more stress regardless of their culture or grade variation. Chandler, Million, and Shermis (1985), in a study involving parents' 
reports of children's stressors, found the number of stressful life events reported to increase with age. Coddington (1972) developed a Life Event Record to measure stress in children and found that age was relevant to children in the rating of perceived stressors, with older children rated as more stressed.

Rutter (1988) also acknowledged differences in stress based on gender. Specifically, he found that boys tended to show greater response and be more vulnerable to stress in situations such as family disharmony and/or changes in primary caretakers.

Conclusion. The research supports the concept that children do experience stress, and they can be reliable reporters of their own stress. A number of types of stressors have consistently been identified in the research literature. In addition, there is documentation that indicates that war may be an additional stressor in the lives of children, that family involvement in war creates stressors for children if the war is on home territory. Age and gender have been found to be factors in determining how stress is perceived. As a result of these studies, it is hypothesized that children perceive events in their lives that are stressful, that children are good reporters in identifying their own stressors, that war may be rated as a stress-inducing factor and that age (grade) and gender are related to perceived stressors. 
Method

Source of Data

In the winter of 1991 school psychology students at the University of Rhode Island prepared intervention teams to work with school administrators on the anticipated impact of the Persian Gulf crisis. Several public school districts in Rhode Island expressed interest in using these teams. In order to understand the impact and to help teachers plan appropriate interventions, a survey was created and administered in October and November of 1991 to samples of students in school districts selected to represent the population density and urban/rural nature of the state. In order to arrive at this division, each of the 37 districts in Rhode Island were rank ordered by total school population into large (over 4000), medium (501-3999), and small (below $500)$ groups, and then further subdivided into urban,.. suburban, and rural districts according to the density of population and commerce. See Table 1 for details of community demographics. Providence was selected to represent urban areas, Bristol represented suburban areas, and Little Compton represented rural areas. Fifth and seventh grade students were chosen because of the appropriateness of the instrument. Subjects

A total of 842 participants from fifth and seventh grade in Providence, Little Compton, and Bristol school 
districts participated in this study. Fifth graders

included 214 males and 209 females; seventh graders included 199 males and 220 females. There were 410 students from the Providence District of which 92 students were Black, 155 were White, 106 were Hispanic and 57 were classified as from other races. In Little Compton there were 18 Blacks, 18 Table 1.

Demographics of School Districts Used in Study

\section{District 1: Providence Students \\ Resources}

Public 19757

Non-Public 5209

Capita Income $\$ 9,501$

Graduation Rate: 57.6

Annual Dropout

Rate: 13.6
Median Family Income $\$ 14,948$

Per

Education Revenues $\$ 102,177,319$

Cost Per Pupil

$\$ 5,329$

\section{District 2: Little Compton Students \\ Public $\quad 317$ \\ Non-Public 36 \\ Resources \\ Graduation Rate: ... \\ Annual Dropout \\ Rate: ...

$\begin{array}{lr}\text { Median Family Income } & \$ 21,130 \\ \text { Per Capita Income } & \$ 12,785 \\ \text { Education Revenues } & \$ 2,711,164 \\ \text { Cost Per Pupil } & \$ 5,809\end{array}$ \\ District 3: Bristol \\ Students \\ Public 2360 \\ Non-Public 669 \\ Resources \\ Graduation Rate: 78.5 \\ Median Family Income \\ $\$ 18,122$ \\ Annual Dropout \\ Rate: 5.8 \\ Per Capita Income \\ $\$ 9,750$ \\ Education Revenues $\$ 12,274,559$ \\ Cost Per Pupil \\ $\$ 5,277$}

Rhode Island Public Schools 1989 Education Indicators,

Rhode Island Department of Education, January, 1990.

Whites, 25 Hispanic and 32 other participants from other races. Bristol was represented by 20 Blacks, 298 whites, 17 Hispanic and 4 other races. For a breakdown of grade, 
gender, and race, see Table 2. All students from each of the fifth and seventh grade classes in all three districts were included in the study with the exception of students in self-contained classrooms.

Measure

A 45-item questionnaire using a five-point Likert scale (one being not upsetting at all, and five being extremely upsetting) was the self report stress measure used in this study. The questionnaire was adapted from Colton's (1985) Children's Own Perceptions and Experiences of Stressors (COPES). Colton developed her 60-item self report measure to determine possible stressors in children's lives.

Table 2.

Sample Description

Race

$\underline{\text { Sex }}$

Grade

Fifth Seventh Total

$\overline{\text { Black }}$

\begin{tabular}{lllr} 
Male & 33 & 37 & 70 \\
Female & 33 & 27 & 60 \\
\hline Total & 66 & 64 & 130
\end{tabular}

White

\begin{tabular}{llll} 
Male & 135 & 106 & 241 \\
Female & 128 & 102 & 230 \\
\hline Total & 263 & 208 & 471
\end{tabular}

Hispanic

Male

Female

24

38

62

Total

29

57

86

Other

Male

22

18

40

Female

19

34

Total

TOTALS

423

52

419 53

93

The Colton scale was chosen because the scale was generated 
from children's self report perceptions of stress, thereby fitting the design of this study. In addition, Colton's subjects were students from fourth and eighth grade classes, which most closely duplicates the sample in this study. Colton selected items from various existing scales in the development of her questionnaire, including items from scales developed by Chandler, 1984; Coddington, 1972; Dobson and Metcalf, 1983; Phillips, 1978; and Yamamoto, 1979.

A 10-factor solution using varimax rotation of the Colton scale produced seven interpretable factors; Isolation, Major Life Events, Family Disruptions, Cognitive Overload, Financial Concerns, Step-Families, and School Problems. Internal consistency estimates, based on Cronbach's alpha, were .92, .90,.87, .76, .77, .96, and .71 respectively. These seven factors accounted for $44.5 \%$ of the total variance. Thirteen of Colton's original items, which failed to load on any factor, were eliminated in this study in order to simplify and shorten the scale. Further reduction of Colton's original scale was done by removing another fourteen items that had the weakest factor loadings in those categories that had numerous loadings, thus retaining the items that contributed the most to the true score variance. The items retained from Colton's scale were taken from each of her seven factors and break down as follows: from the factor labeled Financial Concerns, 3; Step Families, 1; School Problems, 2; Isolation, 10; Major 
Life Events, 8; Family Disruptions, 4; and Cognitive Overload, 5. To address whether war is perceived as a distinct stressor, twelve war-related questions were interspersed with the remaining 33 questions. These war questions were developed by a research group interested in examining the effects of war on children. In the development and acceptance of each question, consideration was given to the matching of the terminology of the colton scale, and the careful wording of questions to avoid perceived socially desirable answers. One of the original questions was also considered potentially applicable to war: 'Someone you love or care about dies'. This, in combination with the twelve new items, resulted in a total of 13 questions thought to be related to war. See Appendix A for complete revised scale.

\section{Procedures}

The questionnaire was distributed to each of the fifth and seventh grade classes in three school districts. In Providence, 192 males and 218 females were administered the questionnaire; in Little Compton 43 males and 50 females were administered the questionnaire and in Bristol 178 males and 161 females were administered the questionnaire, for a total of 842 students. The classroom teachers administered the questionnaire, comprised of 45 potential stress items to be rated and six questions relating to demographics. All teachers used specific guidelines established for 
administration as reported in Appendix B. Trial administration of the questionnaire to ten fifth and seventh graders not included in this study averaged 30 minutes to complete. Thus, teachers were instructed to allow the children 30 minutes to complete the questionnaire and were asked to complete the administering of the questionnaire within a two-week period. 
Results

The purpose of this study was to examine children's perception of potentially stressful events, in general, and events related to war, specifically. Questions addressed were: (a) Are there clusters or groupings of experiences perceived to be stressful by children? (b) Is war perceived as a distinctive stressor by children? (c) Are there group differences (grade and gender) in children's reports of perceived stressful experiences, especially those experiences related to war issues? and (d) Does the involvement of a family member in war influence children's perceptions of war stressors?

Data were collected from fifth and seventh graders $(n=842)$ in Providence, Bristol and Little Compton, Rhode Island. The pool of subjects consisted of 214 male and 209 female students in fifth grade and 199 male and 220 females in seventh grade. Classroom teachers administered a 45-item self-report questionnaire which was developed for this study. Item means and standard deviations are reported in Appendix C.

Question A: Are there clusters or grouping of experiences perceived to be stressful by children?

To answer the first question, a principal components analysis (BMDP, Statistical Software, Inc., 1990) was done, using all 45 questionnaire items combining males and females, fifth and seventh graders, to determine if there are clusters or groupings of experiences perceived to be 
stressful by children. The following criteria were used to determine which components to retain: each rotated factor should have at least three loadings of .40 or greater, and the resultant component structure should be interpretable (Zwick \& Velicer, 1986).

The correlation matrix revealed generally low to moderate correlations across variables. The correlation matrix can be seen in Appendix C. An oblique rotation, which allows for the possibility of relationships among the variables and their emerging components (Velicer \& Jackson, $1990)$ was chosen. The unrestricted oblique rotation yielded eight components that accounted for $50 \%$ of the variance, with 898 of the items loading on these eight components. However, the eighth component did not meet the criterion of having a minimum of three loadings. Therefore, seven interpretable components emerged which are shown in Table 3 .

Table 3 .

Oblique Rotated Principal-Factor Loadings for the Stress Self-Report Measure

Loadings for Stress Factors

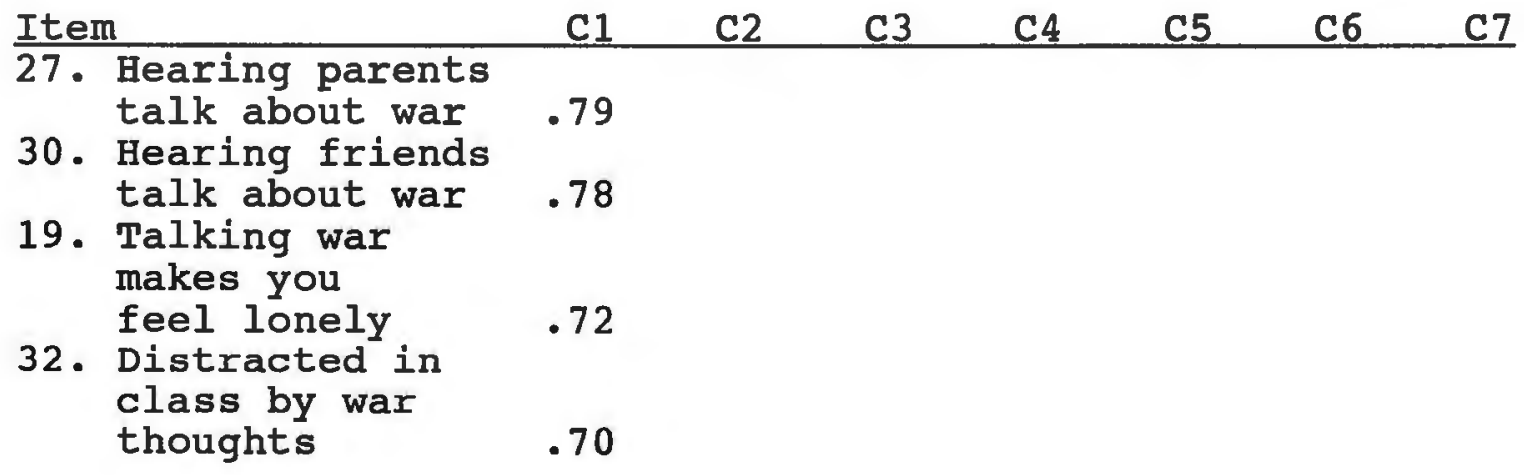


Table 3. (cont'd)

Oblique Rotated Principal-Factor Loadings for the Stress Self-Report Measure

Loadings for Stress Factors

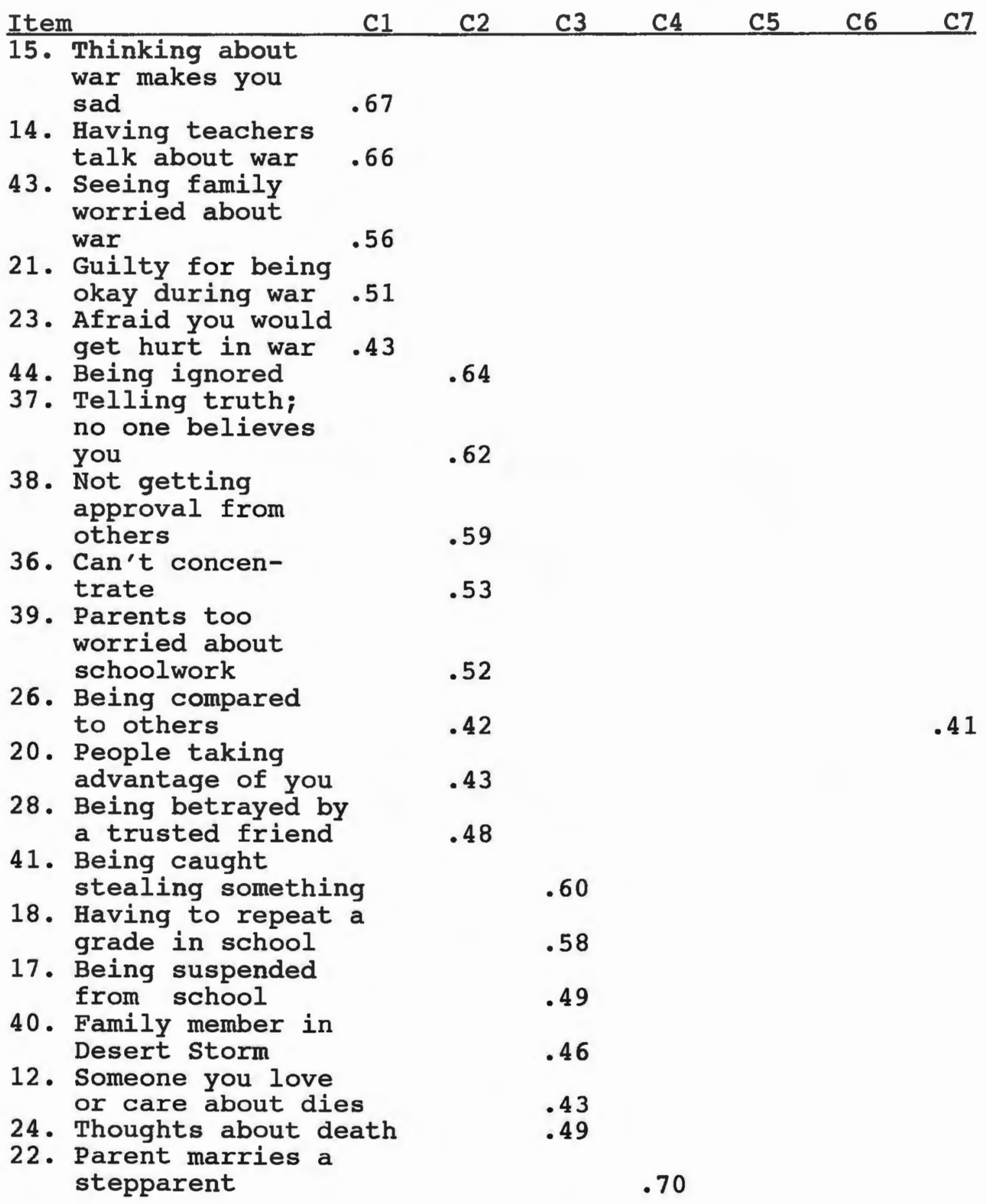


Table 3. (cont'd)

Oblique Rotated Principal-Factor Loadings for the Stress Self-Report Measure

Loadings for Stress Factors

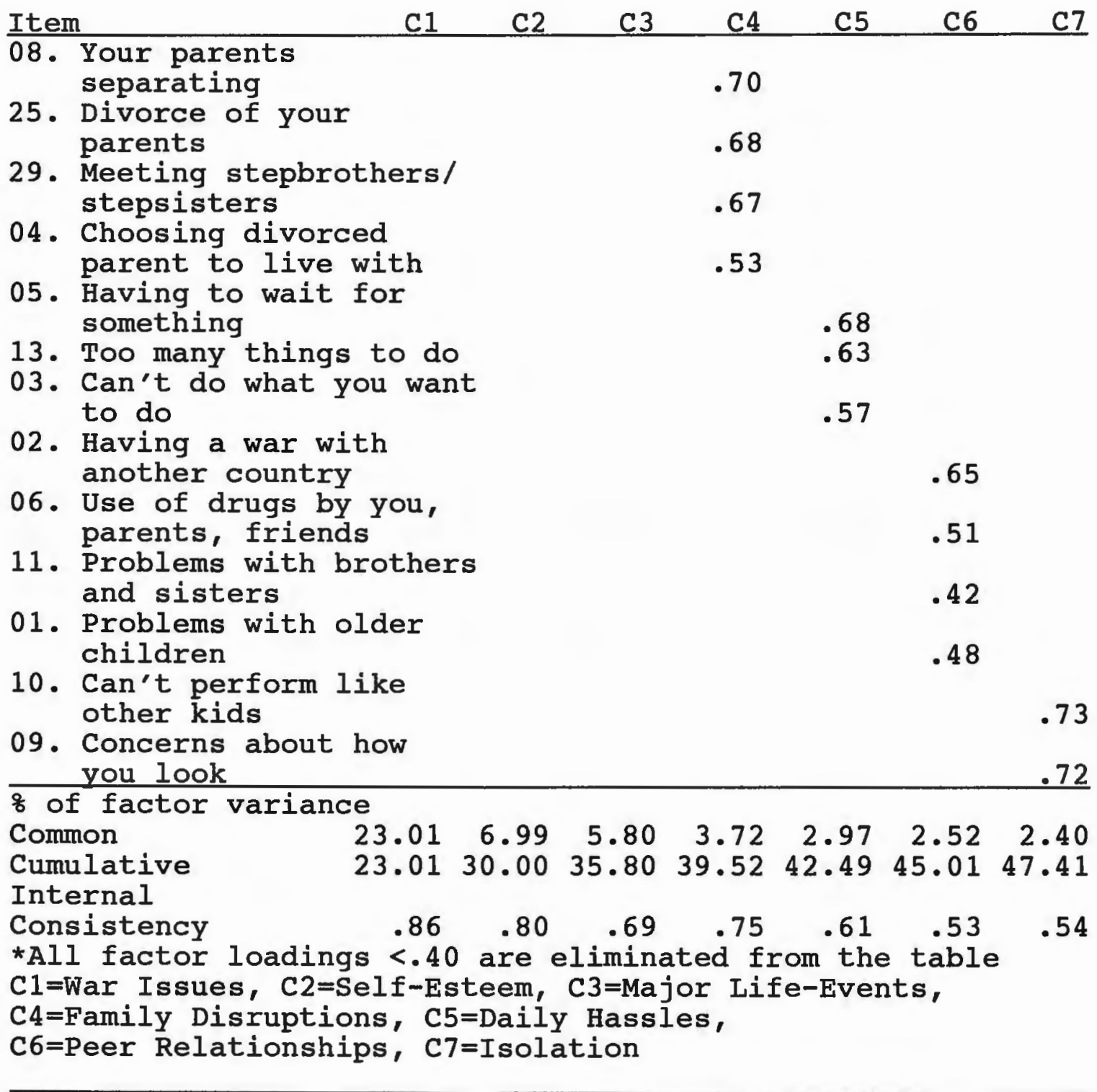

Eight of the individual items failed to load on any component. These items, and their means and standard deviations are shown in Table 4.

The seven identifiable components, accounting for $47 \%$ 
of the cumulative variance, were labeled: War Issues, SelfEsteem, Major Life Events, Family Disruptions, Daily

Hassles, Peer Relationships, and Isolation. Thirty-seven of the 45 items or $82 \%$, loaded on these seven components.

Internal consistency coefficients for the seven components, based on Cronbach's (1951) alpha coefficient ranged from .53 to .86 with a median of .69 (Table 5). The highest internal consistency of .86 was associated with the War Issues component.

Table 4 .

Means and Standard Deviations of Ratings on Items

Without Significant Factor Loadings

\section{Item}

Mean

SD

7. Worrying a war may raise the price of things (food, clothing, gas)

3.21

1.31

16. Being laughed at, teased, made fun of, or called names

3.61

1.41

31. Physical child abuse (getting beaten)

33. You don't have enough money

34. Hearing your parents argue and fight

35. Use of alcohol by you, your parents, or your friends

42. Your parents lose their jobs

45. Trouble with reading, writing, spelling or math

4.19

1.31

3.35

1.45

4.09

1.21

3.91

1.35

4.01

1.23

3.49

1.44

The primary component, War Issues, accounted for $23 \%$ of the item variance, with nine of the 12 war items loading on this component. The breakdown of variance contributed by the remaining components was: Self-Esteem, $7 \%$ of the variance; Major Life Events, 6\%; Family Disruptions, 48; Daily Hassles, 38; Peer Relationships, 38; and Isolation, 28 of 
the variance.

Table 5 gives a review of the correlation matrix relating the seven components to each other and showed generally low to moderate correlations across all of the components.

For example, a low correlation $(r=.074)$ was obtained between C1 (War Issues) and C5 (Daily Hassles), whereas a moderate correlation $(r=.578$ ) was found between C2 (SelfEsteem) and C7 (Isolation). The highest communality, which was $34 \%$, occurred between C2 (Self-Esteem) and C7 (Isolation). The lowest communality, which was $1 \%$, occurred between C1 (War Issues) and C5 (Daily Hassles).

\section{Table 5.}

Correlation Matrix for $\mathrm{C} 1, \mathrm{C} 2, \mathrm{C} 3, \mathrm{C} 4, \mathrm{C} 5, \mathrm{C} 6 \& \mathrm{C} 7$

\begin{tabular}{|c|c|c|c|c|c|c|c|}
\hline $\mathrm{C} 1$ & $\begin{array}{c}\mathrm{C} 1 \\
1.000\end{array}$ & $\mathrm{C} 2$ & $\overline{C 3}$ & $\overline{C 4}$ & C5 & C6 & C7 \\
\hline $\mathrm{C} 2$ & .442 & & & & & & \\
\hline C3 & .484 & .516 & & & & & \\
\hline $\mathrm{C} 4$ & .271 & .381 & .434 & & & & \\
\hline C5 & .074 & .421 & .125 & .139 & & & \\
\hline $\mathrm{C} 6$ & .384 & .431 & .414 & .375 & .201 & & \\
\hline C7 & .303 & .578 & .317 & .310 & .348 & .328 & \\
\hline \multicolumn{8}{|c|}{$\begin{array}{l}\text { C1=War Issues, C2=Self-Esteem, C3=Major Life Events, } \\
\text { C4=Family Disruptions, C5=Daily Hassles, } \\
\text { C6=Peer Relationships, C7=Isolation }\end{array}$} \\
\hline
\end{tabular}


Question B: Is war perceived as a distinctive stressor by children?

In answer to the second question - Is war perceived as a distinctive stressor? - nine of the 12 items designed as war items loaded on the first component and these accounted for $23 \%$ of the total variance. Of the variance accounted for by the seven components, War Issues contributed $49 \%$. It should be noted that although the war items accounted for $49 \%$ of the variance, they represented $27 \%$ of the original item pool which was a disproportionately high percentage of the total number of items.

Question C: Are there group differences (grade and gender) in children's reports of perceived stressful experiences, particularly those experiences related to war?

To address the third question, whether there were group differences (grade and gender) in reports of stressful experiences, especially those experiences related to war issues, a mixed factorial design having two independent groups (grade and gender) of two levels each and one repeated measure (the seven components) ( $\mathrm{AxBx}[\mathrm{CxS}])$. There were significant main effects for grade, $F(1,764)=20.32$, $\mathrm{p}<.01$, and significant main effects for gender, $F(1,764)=$ $47.67, \mathrm{p}<.01$. Fifth graders $(M=3.26)$ rated events overall as more stressful than seventh graders $(M=3.07)$, and females $(M=3.31)$ rated events more stressful overall than males $(M=3.02)$ as shown in Table 6 .

There also were significant main effects for components as adjusted for Geisser-Greenhouse $F(5.09,3886.47)=$ 
$454.60, \mathrm{p}<.01$, indicating that some components were rated higher than others. However, the effects of the components were examined in relation to their significant interractions

Table 6 .

Means and Standard Deviations on

Components C1, C2, C3, C4

\begin{tabular}{|c|c|c|c|c|c|c|c|c|}
\hline & \multicolumn{2}{|c|}{ C1 } & \multicolumn{2}{|c|}{ C2 } & \multicolumn{2}{|c|}{ C3 } & \multicolumn{2}{|c|}{ C4 } \\
\hline & M & SD & M & $S D$ & M & SD & M & SD \\
\hline Grades & & & & & & & & \\
\hline $\begin{array}{l}5 \text { th } \\
7 \text { th }\end{array}$ & $\begin{array}{l}2.52 \\
2.12\end{array}$ & $\begin{array}{l}.85 \\
.83\end{array}$ & $\begin{array}{l}3.60 \\
3.38\end{array}$ & $\begin{array}{l}.78 \\
.84\end{array}$ & $\begin{array}{l}4.10 \\
3.84\end{array}$ & $\begin{array}{r}.79 \\
.84\end{array}$ & $\begin{array}{l}3.68 \\
3.52\end{array}$ & $\begin{array}{r}.98 \\
1.05\end{array}$ \\
\hline Sex & & & & & & & & \\
\hline $\begin{array}{l}\text { M } \\
\text { F }\end{array}$ & $\begin{array}{l}2.12 \\
2.53\end{array}$ & $\begin{array}{l}.79 \\
.88\end{array}$ & $\begin{array}{l}3.34 \\
3.64\end{array}$ & $\begin{array}{l}.87 \\
.73\end{array}$ & $\begin{array}{l}3.78 \\
4.17\end{array}$ & $\begin{array}{l}.87 \\
.72\end{array}$ & $\begin{array}{l}3.52 \\
3.69\end{array}$ & $\begin{array}{l}1.02 \\
1.00\end{array}$ \\
\hline
\end{tabular}

C1=War Issues, C2=Self-esteem, C3=Major Life Events, C4=Family Disruptions

Means and Standard Deviations on

Components $\mathrm{C} 5, \mathrm{C} 6, \mathrm{C7}$

\begin{tabular}{|c|c|c|c|c|c|c|}
\hline & C & & C6 & & C7 & \\
\hline & M & SD & $\mathbf{M}$ & $S D$ & M & $S D$ \\
\hline $\begin{array}{c}\text { Grades } \\
5 \text { th } \\
7 \text { th }\end{array}$ & $\begin{array}{l}2.94 \\
2.91\end{array}$ & $\begin{array}{r}.94 \\
.98\end{array}$ & $\begin{array}{l}3.29 \\
2.96\end{array}$ & $\begin{array}{l}.84 \\
.85\end{array}$ & $\begin{array}{l}2.68 \\
2.79\end{array}$ & $\begin{array}{r}.94 \\
1.08\end{array}$ \\
\hline $\begin{array}{r}\text { Sex } \\
M \\
F\end{array}$ & $\begin{array}{l}2.93 \\
2.93\end{array}$ & $\begin{array}{l}.96 \\
.96\end{array}$ & $\begin{array}{l}2.98 \\
3.27\end{array}$ & $\begin{array}{l}.89 \\
.80\end{array}$ & $\begin{array}{l}2.50 \\
2.95\end{array}$ & $\begin{array}{r}.98 \\
.99\end{array}$ \\
\hline
\end{tabular}

C5=Daily Hassles, C6=Peer Relationships, C7=Isolation

with grade and gender. The overall means for each of the components were: $\mathrm{C} 1=2.33 ; \mathrm{C} 2=3.49 ; \mathrm{C} 3=3.98 ; \mathrm{C} 4=3.6$; $\mathrm{C} 5=2.93 ; \mathrm{C} 6=3.13 ;$ and $\mathrm{C} 7=2.73$.

There were significant interaction effects for gender by component $F(5.09,3886.47)=9.10, p<.01$, and for grade 
by component $F(5.09,3886.47)=11.27, p<.01$ (adjusted for Geisser-Greenhouse). To examine these interactional effects, simple effects tests were conducted that revealed significant mean differences for grade at $\mathrm{Cl}$, War Issues, $F(1,764)=46.83, p<.01$; at C2, Self-Esteem, $F(1,764)=$ 15.92, p<.01; at C3, Major Life Events, $F(1,764)=20.56$, p<.01; at C4, Family Disruptions, $F(1,764)=4.52, p<.05$; and at C6, Peer Relationships, $F(1,764)=32.52, p<.01$ ' specifically, the results showed that fifth graders rated events as more stressful than seventh graders on five of the seven components. Two of the components, Daily Hassles and Isolation were rated equally stressful for both fifth and seventh graders. A graphic representation of these results can be found in Figure 1.

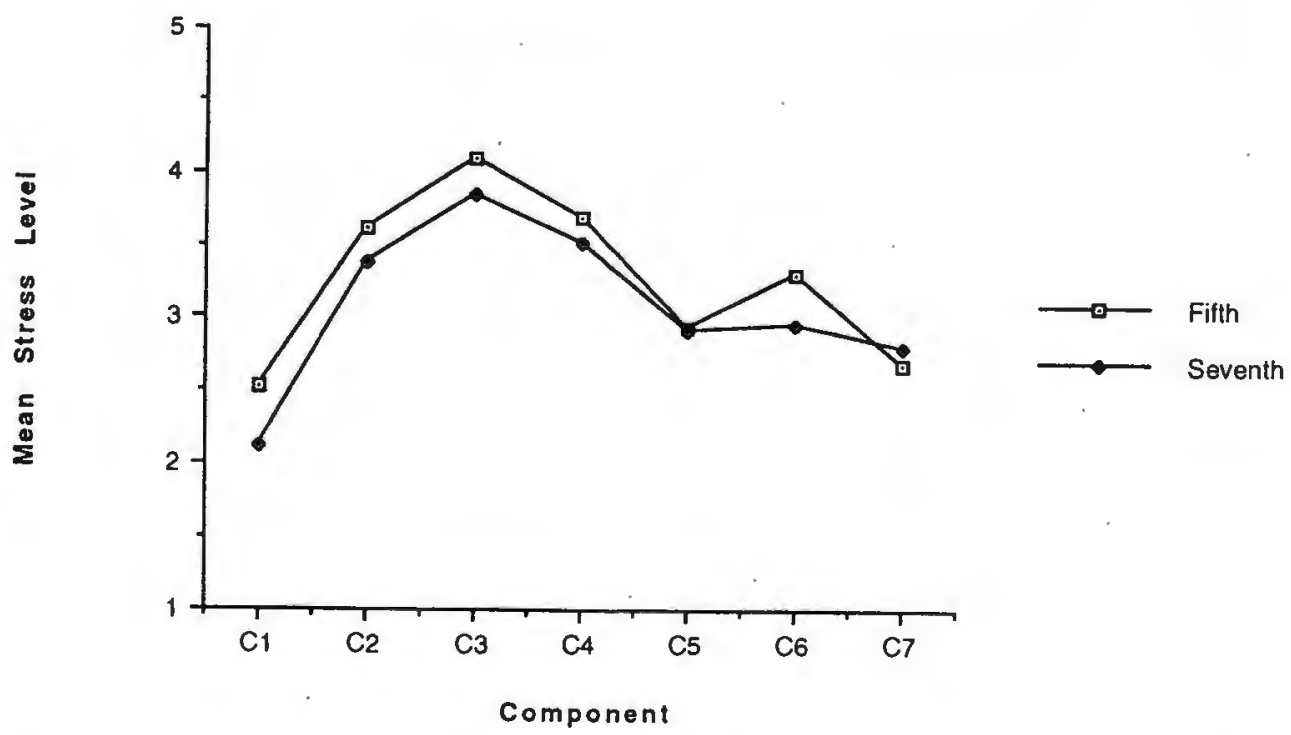

Figure 1. Mean stress level on components for grade 5 and 7 . Note: C1 (War Issues); C2 (Self-Esteem); C3 (Major Life Events); C4 (Family Disruptions; C5 (Daily Hassles); C6 Peer Relationships; $C 7$ (Isolation) 
Significant differences were also found for the simple effects of gender. Females rated events as more stressful than males on six of the seven components: C1, War Issues, $F(1,764)=49.86, p<.01 ; C 2$, Self-Esteem, $F(1,764)=26.85$, p<.01; C3, Major Iife Events, $F(1,764)=48.28, p<.01 ; C 4$, Family Disruptions, $F(1,764)=4.71, p<.05 ; \mathrm{C} 6$, Peer Relationships, $F(1,764)=23.83, p<.01$; and $C 7$, Isolation, $F(1,764)=39.08, p<.01$. The fifth component, C5 (Daily Hassles) showed no significant differences between males and females (see Figure 2).

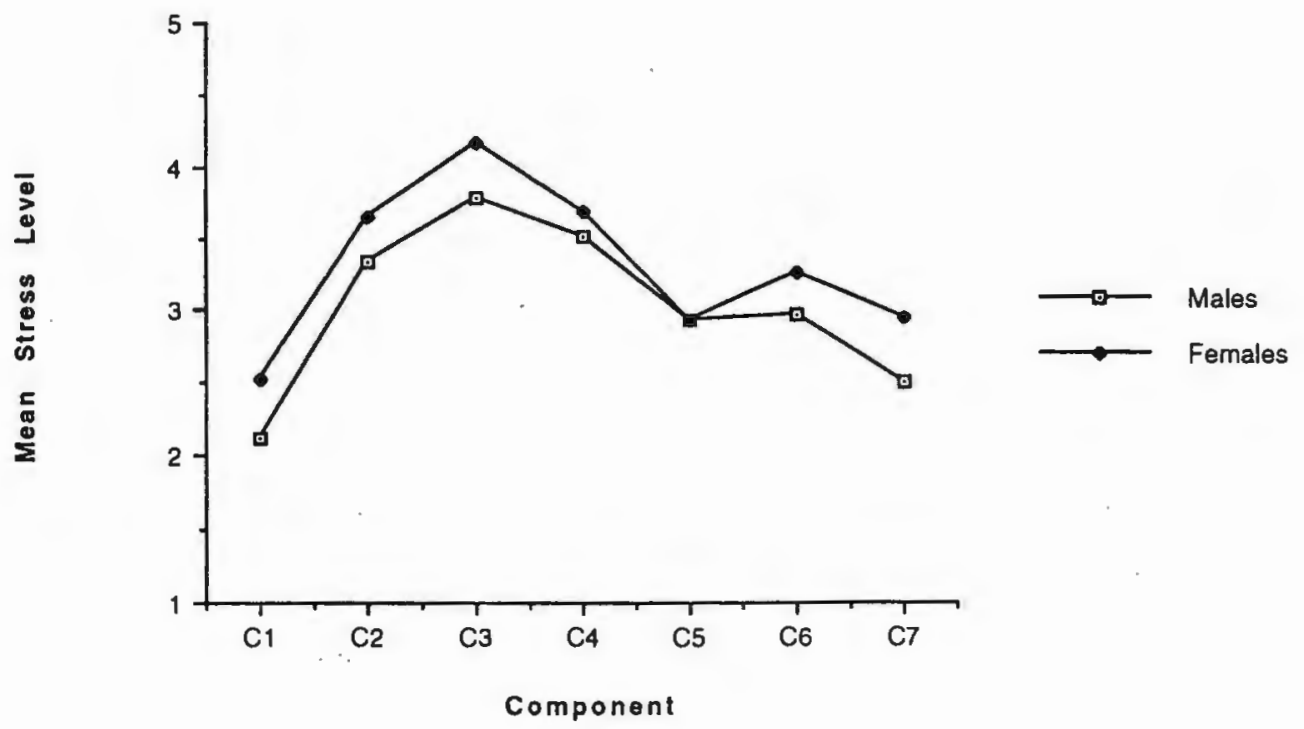

Figure 2. Mean stress level on components for males and females.

Note: C1 (War Issues); C2 (Self-Esteem); C3 (Major Life Events); C4 (Family Disruptions; C5 (Daily Hassles); C6 Peer Relationships; C7 (Isolation) 
each level of the independent variables (grade and gender) constant, further analyses were conducted to determine if there were significant mean differences between each of the seven components at each level of grade and gender. Simple main effects tests, adjusted for Geisser-Greenhouse, showed significant differences among the seven components: males $\mathrm{F}(5.06,3873.61)=229.30, \mathrm{p}<.01$; females $\mathrm{F}(5.06,3873.61)=$ $227.83, p<.01$; fifth graders $F(5.07,3885.77)=248.62$, p>.01; and seventh graders $F(5.07,3885.77)=211.94$, ip<.01. Simple comparisons were conducted using the Tukey test to further break down the analysis.

The relative ordering of stressors by fifth graders were: Major Life Events $(M=4.1)$, Family Disruptions $(M=3.68)$, Self-Esteem ( $M=3.6)$, Peer Relationships ( $M=3.29)$, Daily Hassles $(M=2.94)$, Isolation $(M=2.68)$, and War Issues $(M=2.52)$. All were significantly different from each other at the .01 level with the exception of Isolation ( $M=2.68$ ) and War Issues $(M=2.52)$ which did not differ significantly. For seventh graders, the same rank ordering occurred. However, Family Disruptions $(M=3.52)$ and Self-Esteem ( $M=3.37)$ were not significantly different, nor were Peer Relationships ( $M=2.95)$, Daily Hassles $(M=2.91)$ and Isolation $(M=2.79)$. Males responses were also similarly rank ordered, with non-significant differences between Family Disruptions $(M=3.52)$ and Self-Esteem $(M=3.34)$ and between Peer Relationships $(M=2.98)$ and Daily Hassles $(M=2.93)$. Female 
responses were ordered as follows: Daily Hassles ( $M=4.17)$, Peer Relationships (M=3.68), Isolation (M=3.63), Family Disruptions $(M=3.27)$, Major Life Events $(M=2.94)$, SelfEsteem $(M=2.93)$, and War Issues $(M=2.53)$. Peer

Relationships and Isolation were not significantly different from each other, nor were Major Life Events and Self-Esteem (Table 7).

\section{Table 7 .}

Component Means at Each Level of Grade and Gender

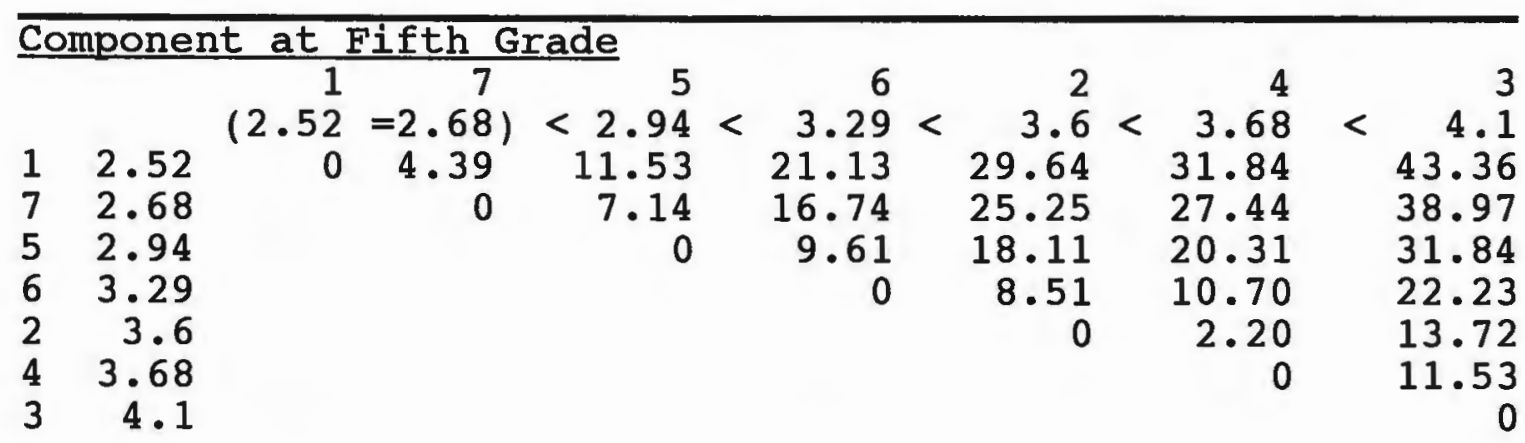

Component at Seventh Grade

\begin{tabular}{rrrrrrrrr}
\hline & & 1 & 7 & 5 & 6 & 2 & 4 & 3 \\
1 & 2.12 & $0.12<(2.79$ & 2.91 & $2.95)$ & $<(3.37$ & $=3.52)$ & 3.84 \\
7 & 2.79 & 0 & 17.27 & 20.37 & 21.40 & 32.22 & 36.09 & 44.34 \\
5 & 2.91 & 0 & 3.09 & 4.12 & 14.95 & 18.82 & 27.07 \\
6 & 2.95 & & 0 & 1.03 & 11.86 & 15.73 & 23.97 \\
2 & 3.37 & & & 0 & 10.83 & 14.69 & 22.94 \\
4 & 3.52 & & & & & 0 & 3.87 & 12.12 \\
3 & 3.84 & & & & & & 0 & 8.25 \\
& & & & & &
\end{tabular}

Component at Male

\begin{tabular}{rrrrrrrrr}
\hline & & 1 & 7 & 5 & 6 & 2 & 4 & 3 \\
1 & 2.12 & 0 & 9.93 & 21.17 & 22.48 & 31.88 & 36.59 & 43.38 \\
7 & 2.5 & & 0 & 11.24 & 12.54 & 21.95 & 26.66 & 33.45 \\
5 & 2.93 & & & 0 & 1.31 & 10.71 & 15.42 & 22.21 \\
6 & 2.98 & & & & 0 & 9.41 & 14.11 & 20.91 \\
2 & 3.34 & & & & & 0 & 4.70 & 11.50 \\
4 & 3.52 & & & & & & 0 & 6.79 \\
3 & 3.78 & & & & & & & 0
\end{tabular}


Table 7.

Component Means at Each Level of Grade and Gender

Component at Female

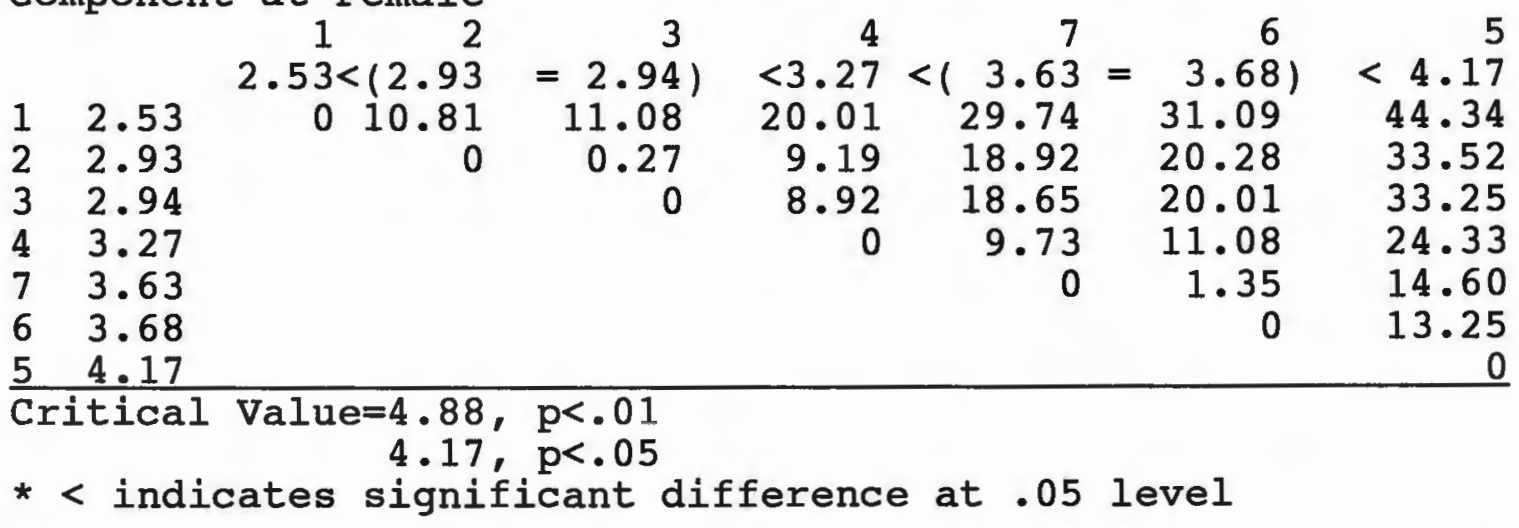

Results indicate that although war Issues accounted for the largest share of the variance in the PCA, a comparison of the component means indicates that concerns about war are not a major stressor in comparison to other stressors in children's lives. Both fifth and seventh grade children perceived Major Life Events as being most stressful. In addition, the males in this study also rated Major Life Events as the highest perceived stress. Females, however, rated Daily Hassles as the highest perceived stress.

Question D: Did the involvement of a family member in the Persian Gulf crisis influence children's perceptions of war stressors?

To address the fourth question, whether the involvement of a family member in the Persian Gulf crisis influenced children's reports of war stressors, a $2 \times 2 \times 2$ ANOVA (gender by grade by involvement) was performed. Due to the smaller percentage of involved subjects in the sample, a randomly selected sub-group of subjects from the non-involved group was used for this analysis. This was done to avoid 
discrepancy in sample sizes between groups. Sample size for this analysis was 137 subjects in the involved group and 143 subjects in the non-involved group. Means and standard deviations of involved and non-involved males and females on war issues are reported in Table 8.

Table 8 .

Means and Standard Deviations of Involved and Non-Involved Males \& Females on War Issues (C1)

\begin{tabular}{llcc}
\hline Item & N & Mean & SD \\
\hline $\begin{array}{l}\text { Non-Involved } \\
\text { Males }\end{array}$ & 74 & 2.16 & .75 \\
Females & 69 & 2.43 & .86 \\
& & & \\
Involved & & 2.18 & .81 \\
Males & 70 & 2.87 & 1.03 \\
Females & 67 & & \\
\hline
\end{tabular}

The results of the $2 \times 2 \times 2$ ANOVA showed significant main effects for grade $F(1,272)=7.55, p<.01$; for gender $F(1$, $272)=18.37, p<.01 ;$ and involvement $F(1,272)=4.31$, p<.05. Consistent with earlier findings, fifth graders $(M=2.55)$ rated War Issues higher than seventh graders $(M=2.26)$. Also, as noted previously, females $(M=2.64)$ rated War Issues higher than males $(M=2.19)$. Finally, children with family member involvement $(M=2.52)$ rated War Issues higher than children with non-involved family members $(M=2.30)$.

There was a significant two-way interaction between gender and involvement $F(1,272)=5.40, \mathrm{p}<.05$. Follow up 
simple effects test showed that females who had family members involved in the Gulf War rated the War Issues component as significantly more stressful than males who had family members involved $F(1,272)=21.09, p<.05$. See Figure 3 .

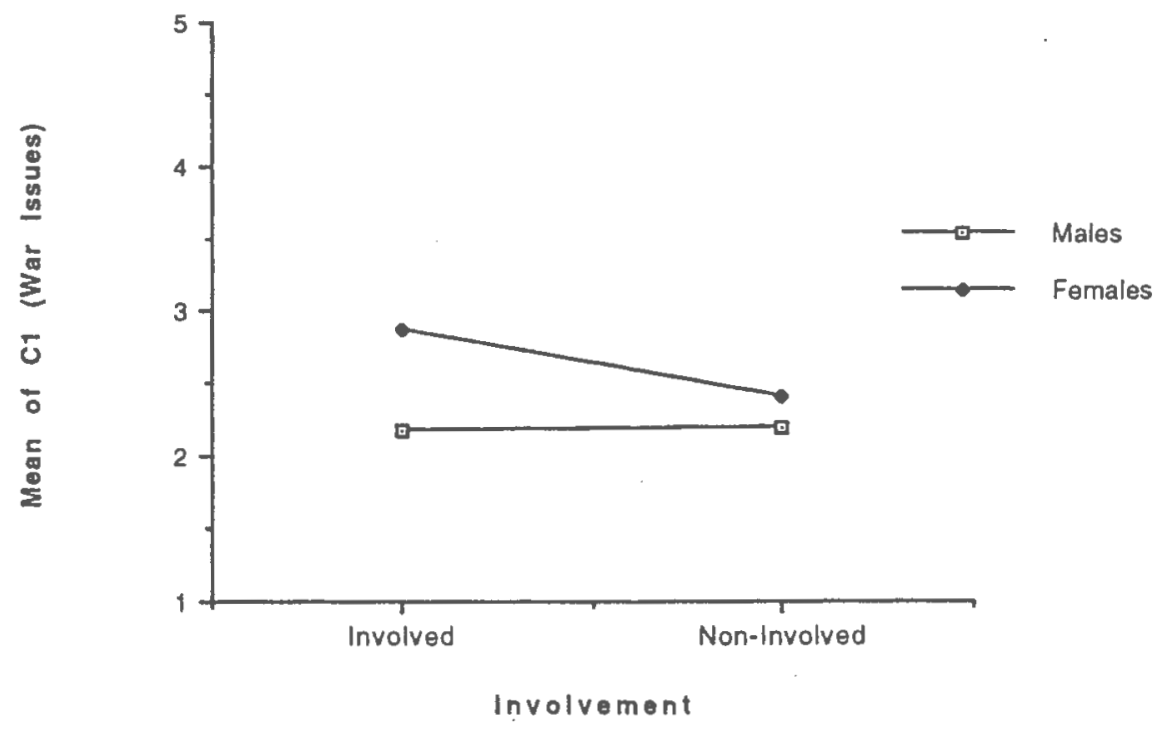

Fiqure 3. Gender by involvement interaction on war issues 


\section{Discussion}

The purpose of this study was to assess children's perceptions of stress, paying particular attention to warrelated stressors. The four questions addressed were: (a) Are there clusters or groupings of events perceived as stressful for children? (b) Is war perceived as a distinctive stressor by children? (c) Are there group differences (grade and gender) in children's reports of perceived stressful experiences, particularly those experiences related to war issues? and (d) Did the involvement of a family member in the Persian Gulf crisis influence children's reports of war stressors? These questions were addressed through a series of analytic procedures using a self-report measure that was administered in the classroom by the classroom teacher.

In answer to the first question, an unrestricted oblique rotation (PCA), of the self-report stress measure identified seven interpretable components. These components were labeled War Issues, Self-Esteem, Major Life Events, Family Disruptions, Daily Hassles, Peer Relationships, and Isolation. The total variance attributed to these components was $47 \%$. Thirty-seven items of the 45 original items, or $82 \%$, loaded on these seven components.

Due to the changes made to accommodate the war questions, exact duplication of the Colton scale, on which the current measure was adapted (i.e., COPES) was not 
expected. Nevertheless, three categories of perceived stress for children that emerged from the COPES were also identified by this study: Isolation, Major Life Events and Family Disruptions. All of the Isolation items in this study loaded on a similar component in Colton's study (i.e., Isolation). The Family Disruption category was also similar to Colton's in that three of the five items loading also loaded on a similar factor (i.e., Family Disruptions in Colton's study). The additional two items that loaded on Family Disruptions in the present study loaded on the StepFamily factor in the colton study, a factor which could be considered similar in nature. In the category labeled Major Life Events, there were only two items that matched the Colton study: "Being caught stealing something", and "Someone you love or care about dies". Results from the current study revealed that three additional items (grade repetition, suspension from school, and thoughts about death) also loaded on the Major Life Events component. The results of the current analysis support that there are groupings or clusters of events perceived as stressful by children. Additionally, the clusters emerging from this study are similar in content to those found by previous researchers (Colton, 1985; Elwood, 1987; Omizo, Omizo, \& Suzuki, 1988), lending support to the argument that these components are representative of children's perceived stressors. 
The principal component analysis of the self-report stress measure was also used to address the second question: "Is war perceived as a distinctive stressor?" The results showed that a War Issues component did emerge in the analysis, accounting for $23 \%$ of the total variance accounted for in the stress measure. Upon closer examination, the results showed that nine of the twelve war questions loaded on the War Issues component. One of the war questions, (i.e., worrying a war may raise the price of things) failed to load on any component. One explanation for the failure of this item to load may be that financial issues may not be a concern for children as young as fifth and seventh graders. Two additional war-related items failed to load on the War Issues component. The first item, which dealt with family member involvement in the war, loaded on the Major Life Events component. Again, this seems to be a reasonable placement because other items loading on that component were related to severe stressors, such as a family member dying and having thoughts about death. The second item that failed to load dealt with having a war with another country, which loaded on the component labeled Peer Relationships, and seems to be the most difficult to interpret. There may be a possibility that war with another country brings up questions in children's minds about interpersonal relationships. Certainly war can be considered tensioncreating and the other items on this component speak to 
tension in interpersonal relationships.

Even though war emerged as distinctive, it was perceived as the least stressful of all the identified areas. The literature supports that children who are directly involved in war are more stressed by war events than children who are not directly involved. It appears possible that children are more concerned with loss of family members and/or possible family displacement than they are about the war itself. This study was conducted shortly after the Persian Gulf crisis, so the timing may have had some bearing on the children's responses. However, not all family members involved in war had returned and yet these chidren still did not report particular concerns about war Issues. In addition, $27 \%$ of the items on the questionnaire were war questions, and this imbalance may account for the strong emergence of the war component.

The third question in the study focused on whether there were significant differences in the rating of stressors between fifth and seventh graders. The analysis revealed that fifth graders showed higher ratings than seventh graders on five of the seven components of perceived stress. The significant components were War Issues, SelfEsteem, Major Life Events, Family Disruptions and Peer Relationships. The two components that were not significant were Daily Hassles and Isolation. Daily hassles are defined as the frustrating and irritating demands of everyday life 
(Kanner, Cayne, Schaefer, \& Lazarus, 1981). The lack of significance may be due to the fact that Daily Hassles are common to everyone, regardless of age, which would explain the similar ratings across grades. Isolation was also a component that showed no significant difference between fifth and seventh graders. However, in Colton's study (1981), Isolation was the one factor that was perceived to be more stressful by younger children than older children. The fifth graders' higher stress levels on the other five components may reflect younger children's anxiety about situations which they do not understand and over which they have little power. This is consistent with Omizo, Omizo and Suzuki (1988) who reported that children feel stressed when they do not feel they have control over the events that are bothering them.

Contrary to some previous research, which shows that older children perceive more stress (Chandler, Million, \& Shermis, 1985; Coddington, 1972), younger children in this study perceive events to be more stressful. In light of Piaget's stages of cognitive development (Siegler, 1991) and Erikson's psychosocial development theory (Thomas, 1992), it is difficult to understand the reasons for higher stress levels reported by younger children, as the older children in this study are just on the threshold of adolescence. The discrepancy in this study may be a reflection of differences between past research, which has dealt more with parental 
reports of children's perceived stressors, and this study which is a self-report measure of stress with children rating their own perceptions of the stressful events. Yamamoto and Felsenthal, 1982; and Yamamoto \& Davis, 1982, have documented a discrepancy between adult perceptions of child stress and children's own perception of stress. Thus, it may be possible that in children rating their own perceived stress is a more accurate method of assessing stress in the lives of children. This could be an important consideration for future research.

There appears to be little research that has looked at gender differences among children's perceptions of stress. However, some research (Yamamoto, 1979; Yamamoto \& Davis, 1982) has shown that differences do exist in the reports of stress between males and females. In their studies, they found that older female children found events more stressful than younger female children, whereas there were no differences between younger male children and older male children. Rutter (1988) found that males experienced higher levels of stress than females particularly on issues relating to family disruptions. In this study significant gender differences were found for children's reports of perceived stress. Specifically, females showed higher levels of stress than males across six of the seven components. As in the area of grade differences, there were no significant differences between males and females on the 
Isolation component. These results warrant future research in order to understand more clearly gender differences. The final question, assessing the results of family member involvement in the Persian Gulf crisis on children's perceived stressors, has interesting results. Females consistently reported higher stress levels than males across most of the components identified in this study and, in the area of family involvement, there was also a significant difference in perceived stressors with females reporting higher stress levels than males. If there was no family involvement in the Gulf War, both males and females rated war as equally stressful. This is inconsistent with research reported by Cohen and Dotan (1976) and Milgram and Milgram (1976), which reported that there was no significant difference between male and females whether or not family was involved. It is difficult to know if the males in this study were less willing than females to admit that events can be stressful since our society has traditionally raised boys to not show emotion and they may be more reluctant than females (Maccoby, 1990) to identify those events that may be considered stressful.

The higher stress ratings reported by females may be a reflection of the earlier development of pro social moral judgment found in females. Eisenberg, Pasternack, Cameron and Tryon (1984) reported that girls of 11 and 12 years of age, compared to boys of the same age, are more role taking, 
other-oriented and sympathetic. Adolescent females also tend to be more self-reflective and other-oriented earlier than males (Eisenberg, Shell, Pasternack, Lenin, Beller \& Mathy, 1987).

The results of this study appear to indicate that war is a distinctive event in children's perceptions of stress, however, the results do not reflect strong concern. This study also indicates that younger children and female children showed higher levels of reported stress across such domains as War Issues, Self-Esteem, Major Life Events, Family Disruptions, Peer Relationships and Isolation, with both fifth and seventh grade children showing Major Life Events as being the most stressful. In addition, males showed Major Life Events as being most stressful, whereas females showed the Daily Hassle component as being the most stressful. Although much of the prior research points to older children reporting more stress than younger children, the results of this study suggest that younger children report more stressful events than older children. Thus, further research is warranted to determine if there are particular types of stressors that affect age groups differently and whether the method of reporting may be contributing to the age and gender differences. The generally higher levels of stress reported by females also warrants further research for the purpose of acquiring a better understanding of what these stressors are and to 
assist females in dealing with difficult events in their lives.

In view of these results, it seems important to continue to explore the differences between self-report measures by children of perceived stressors and professionals' reports of perceptions of children's stressors as well as gender differences in perceptions of stress. 
Appendix A

Questionnaire

These questions are from some people who want to know what things upset children. They would like you to help them by answering the questionnaire.

First we need to know some information about you.

How old are you?

Grade

Boy

Are you: Black

Black (check one)

Another ethnic group Hispanic White

Did you have a family member involved in Desert Storm? Yes No

If yes, how is that person related to you? Mother Father Sister Brother Other

Remember there are no right or wrong answers. Just mark what you think.

THANKS FOR ANSWERING ALI THE QUESTIONS!! 


\section{Appendix A (cont'd)}

Please circle the number for each statement to show how upsetting you think it is or would be for you.

1. Having problems

$$
\begin{gathered}
\text { Not A little Up- Very Extremely } \\
\text { Upsetting Upset- set- Up- } \\
\text { at all ing ting setting setting }
\end{gathered}
$$

with older children. 1

$\begin{array}{llll}2 & 3 & 4 & 5\end{array}$

2. Having a war with

another country.

1

2

3

4

3. Not being allowed to

do something that you want to do.

2

3

4

5

4. Choosing which

divorced parent you

want to live with.

1

2

3

4

5

5. Having to wait for something. 1

2

3

5

6. The use of drugs by you, your parents, or your friends.

1

2

3

4

5

7. Worrying a war may

raise the price of

things (food, clothing, gas).

2

3

4

5

8. Your parent separating.

9. Concerns about how you look (your weight or height).

10. Not being able to perform like other kids, but being expected to do so.

11. Having problems with your brothers and sisters.

12. Someone you love or care about dies. 


$$
\begin{aligned}
& \text { Appendix A (cont'd) } \\
& \text { Not A little Up- Very Extremely } \\
& \text { Upsetting Upset- set- Up- } \begin{array}{c}
\text { Up- } \\
\text { at all ing ting setting setting }
\end{array}
\end{aligned}
$$

13. Too many things to

do. $\begin{array}{lllllll}1 & 2 & 3 & 4 & 5\end{array}$

14. Having our teachers talk about war.

$\begin{array}{lllll}1 & 2 & 3 & 4 & 5\end{array}$

15. Thinking about war makes you sad.

1

2

3

4

5

16. Being laughed at, teased, made fun of, or called names.

1

2

3

4

5

17. Being suspended from school.

2

3

4

5

18. Having to repeat a grade in school.

1

2

3

4

5

19. Thinking about war makes you feel

lonely.

1

2

3

4

5

20. People taking advantage of you.

21. Feeling guilty because things were okay for you when the country was at war. 1

12

2

3

5

22. Marriage of your parents to a stepparent.

23. Being afraid you would get hurt in

a war.

24. Thoughts about death.

25. Divorce of your parents. 
Appendix A (cont'd)

Not A little Up- Very Extremely Upsetting Upset- set- Up- Upat all ing ting setting setting

26. Being compared to others.

1

2

3

4

5

27. Hearing your parents talk about war.

2

3

4

5

28. Being betrayed by someone when you

thought they were your friend and you trusted them.

1

2

3

4

5

29. Meeting with new step-brothers and step-sisters.

1

2

3

4

5

30. Hearing your

friends talk about war.

1

3

4

5

31. Physical child abouse (getting beaten).

1

2

3

4

5

32. Being distracted in

class by thoughts

about a war.

1

2

3

4

5

33. You don't have enough money.

1

2

3

4

5

34. Hearing your parents argue and fight.

1

2

3

4

5

35. Use of alcohol by you, your parents or your friends.

36. Can't concentrate.

1

2

3

4

5

37. Telling the truth but no one believing you.

3

4

5

38. Not getting approval from others.

2




\section{Appendix A (cont'd)}

Not A little Up- Very Extremely Upsetting Upset- set- Up- Upat all ing ting setting setting

39. Parents are too worried about your work.

1

2

3

4

5

40. Having someone in your family serving in Desert Storm.

1

2

3

4

5

41. Being caught stealing something. 1

2

3

4

5

42. Your parents lose their job.

2

3

4

5

43. Seeing that your

family was worried about a war.

1

2

3

4

5

44. Being ignored. 1

2

3

4

5

45. Trouble with reading, writing, spelling, or math. 


\section{Appendix B}

\section{Teacher's Instruction}

Purpose and Goals: A research interest group at The University of Rhode Island is interested in how various life events impact on children's school performance. The recent events in the Middle East gave impetus to a study which examines the effect of war on school age children. In order to assess the effects of war and other worries on children, the enclosed questionnaire was developed. Past research suggests that children's concerns about war appear to be more adults' projections than children's issues. The current survey is an attempt to clarify this question. We are hopeful that the results of this study will assist you in planning school activities that meaningfully address your students' concerns. The results of this study will be shared with your school.

Administration Time: Approximately 30 minutes.

\section{Procedure:}

Step 1: Read the front page to the children having them answer each of the information questions as you go along. When reading the question about whether the children have a family member serving in Desert storm, explain to the children that they should check YES if any of their family members were or currently are in the Middle East. Wait until everyone has completed the front page before proceeding to the questionnaire.

Step 2: In order that the entire class is basing their answers on the same set of criteria the teacher (or whoever is administering the test) should provide the class with the following definition of stress.

Stress is an unpleasant or upsetting feeling that occurs in situations that are unpleasant or upsetting. It can be physical or emotional.

Step 3: Teachers should read the example provided below and go through the rating scale with the class.

How stressful do you think it would be for you to get lost in a strange place? Would it be:

1) not upsetting at all, if so circle number 1 .

2) a little upsetting, if so circle number 2 .

$3)$ upsetting, if so circle number 3 .

$4)$ very upsetting, if so circle number 4 .

5) extremely upsetting, if so circle number 5 . 


\section{Appendix B (cont'd)}

Step 4: Read each of the items on the questionnaire, allowing approximately 15 seconds after each question for the children to mark their answers. You can explain the meaning of any word a child does not understand.

The completed questionnaires will be picked up by a member of the research team on October 28, 1991. If you have any questions about the survey, please feel free to contact the research coordinator, Elaine C. Lee, at (203) 572-9259, or Janet Kulberg, Ph.D., University of Rhode Island, Psychology Department, at 792-4228. 
Appendix C

Table 9 .

Means and Standard Deviations of Ratings on Items

With Significant Factor Loadings

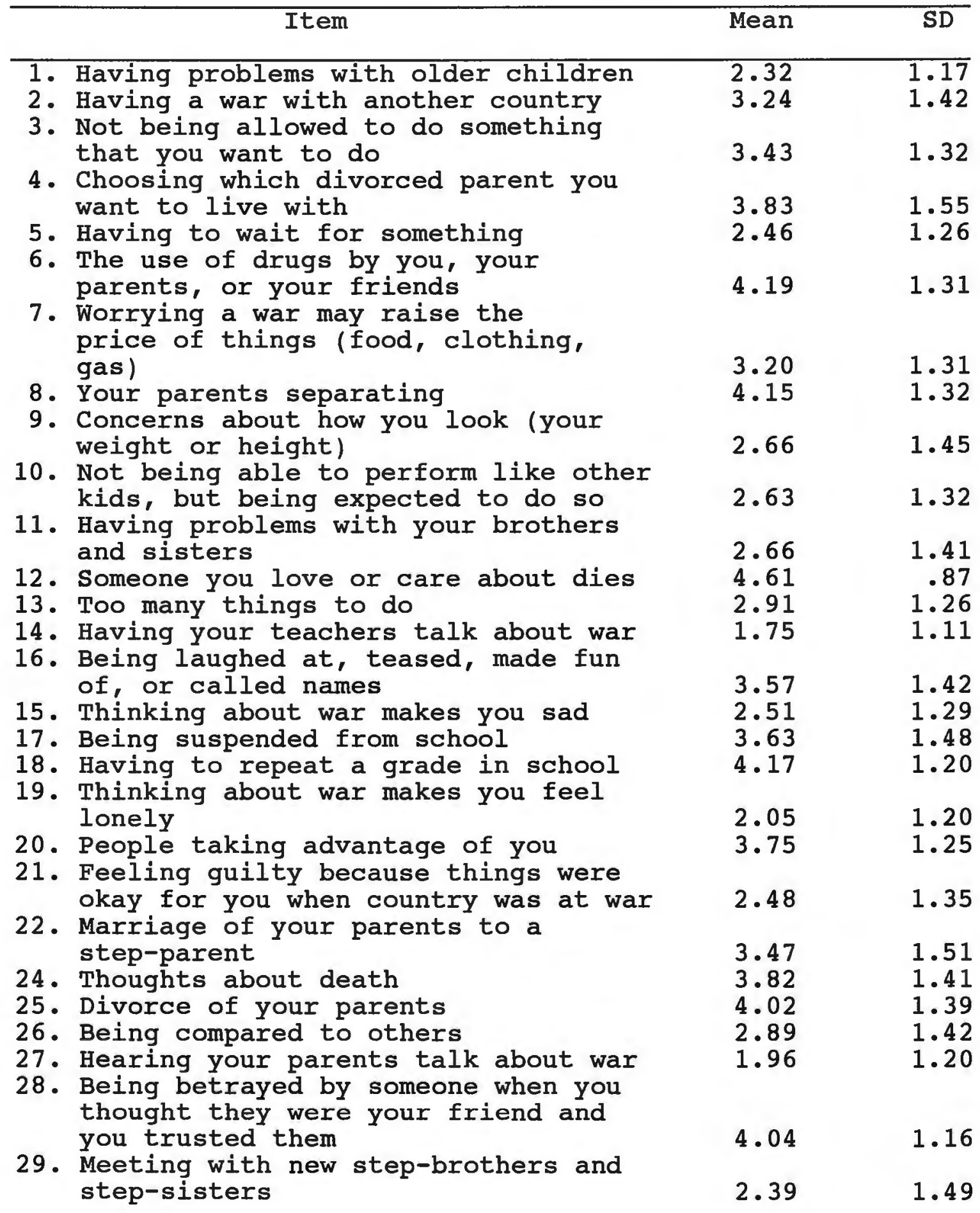


Table 9

Appendix C (cont'd)

Means and Standard Deviations of Ratings on Items

With Significant Factor Loadings

\begin{tabular}{|c|c|c|}
\hline Item & Mean & SD \\
\hline $\begin{array}{l}\text { 30. Hearing your friends talk about war } \\
\text { 31. Physical child abuse (Getting } \\
\text { beaten) } \\
\text { 32. Being distracted in class by } \\
\text { thoughts about a war } \\
\text { 33. You don't have enough money } \\
\text { 34. Hearing your parents argue and fight } \\
\text { 35. Use of alcohol by you, your parents, } \\
\text { or your friends } \\
\text { 36. Can't concentrate } \\
\text { 37. Telling the trust but no one } \\
\text { believing you } \\
\text { 38. Not getting approval from others } \\
\text { 39. Parents are too worried about } \\
\text { your school work } \\
\text { 40. Having someone in your family } \\
\text { serve in Desert storm } \\
\text { 42. Being caught stealing something } \\
\text { 43. Your parents lose their jobs } \\
\text { woing that your family was } \\
\text { 44. Being ignored a war } \\
\text { 45. Trouble with reading, writing, } \\
\text { spelling or math }\end{array}$ & $\begin{array}{l}2.17 \\
3.36 \\
4.06 \\
3.88 \\
3.18 \\
4.14 \\
3.03 \\
3.10\end{array}$ & $\begin{array}{l}1.51 \\
1.33 \\
1.23\end{array}$ \\
\hline
\end{tabular}




\section{Appendix $\mathrm{C}$}

Table 10

\section{Correlation Matrix}

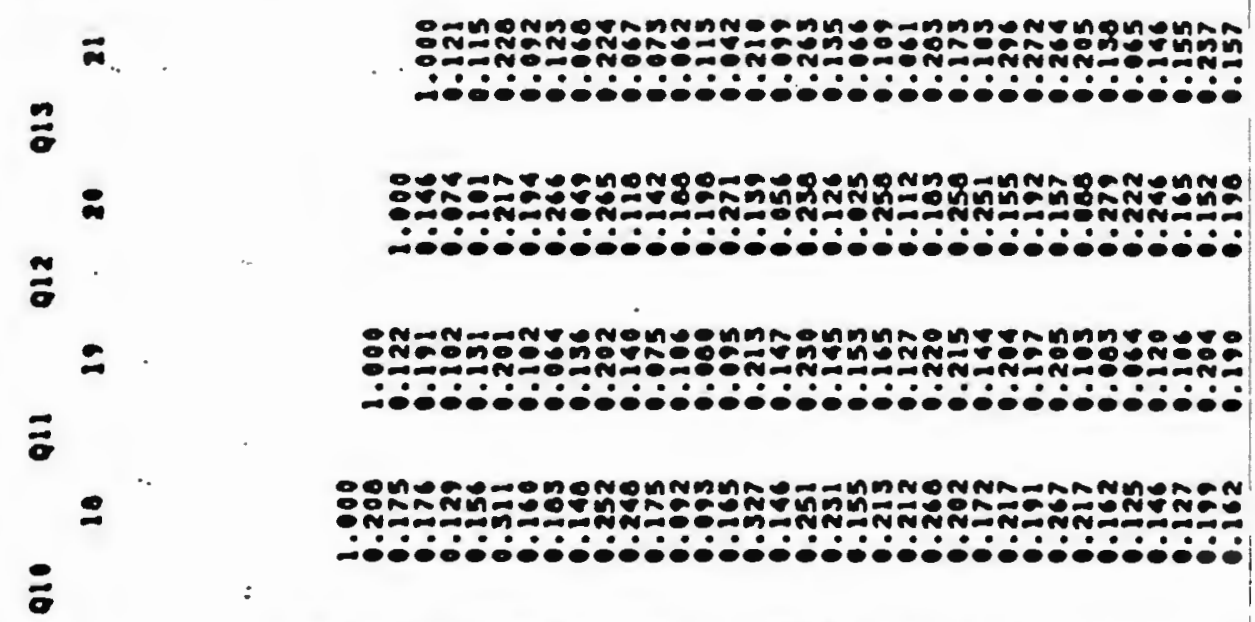

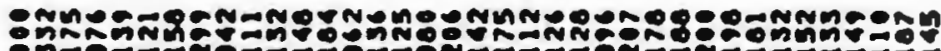
On- N. -1 -

:

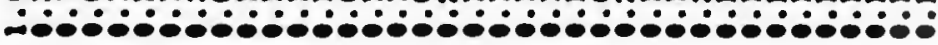

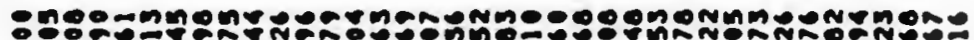

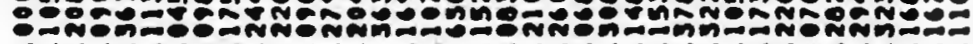

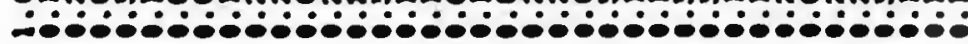

8

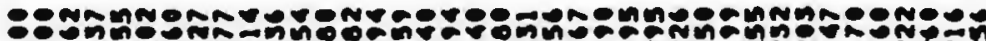

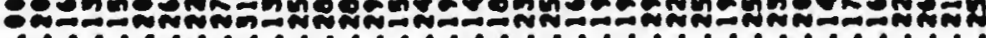

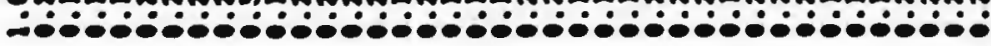

a

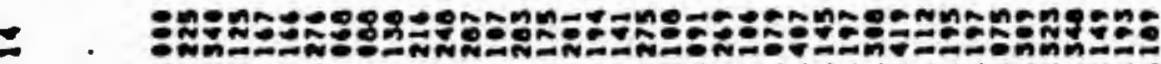

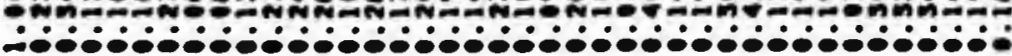

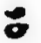

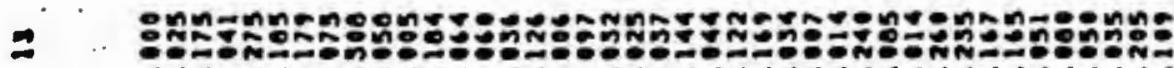

今

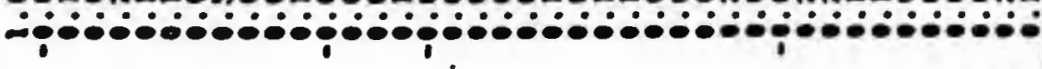

今

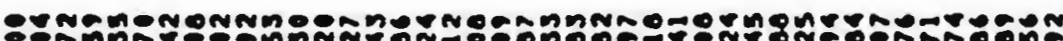

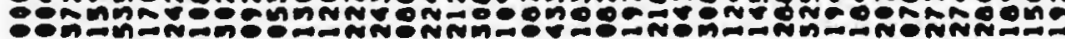

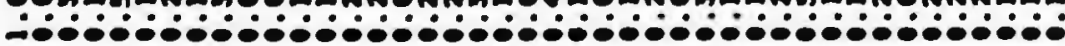

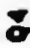

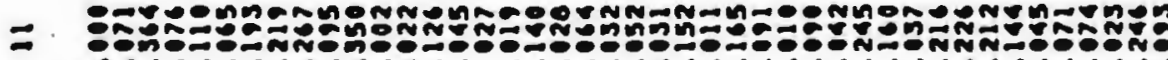

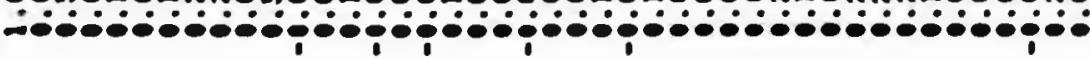

?

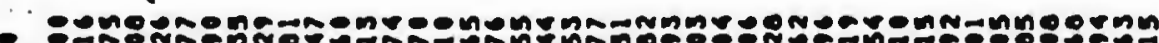

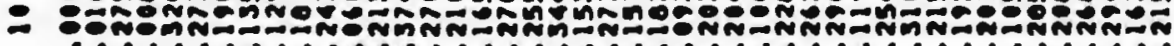

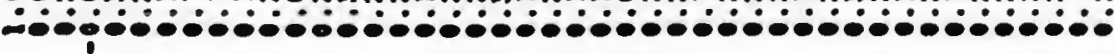

$\approx$

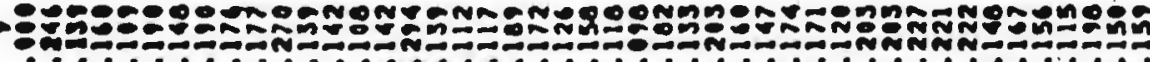

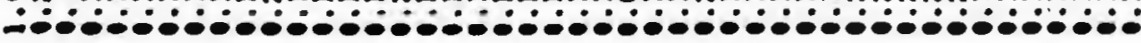

$\approx$

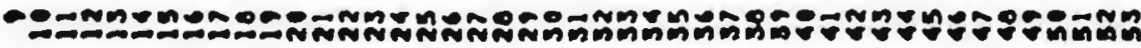

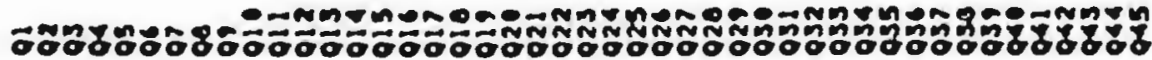




\section{Appendix C (cont'd)}

Table 10

Correlation Matrix

in $\quad$ :xตี

มู

d.

$\approx$

${ }^{*}$

$\overbrace{}^{2}$

2

8

-

๘

8

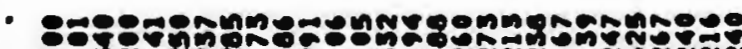

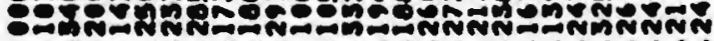

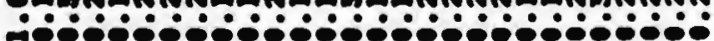

$\%$

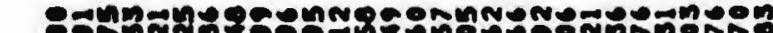

A BO-ANA

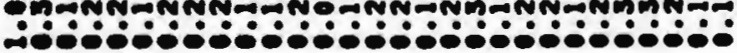

‡

$\dot{2}$

ב

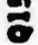

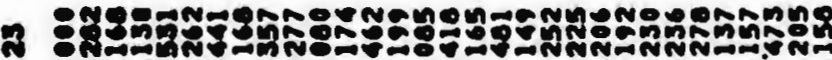

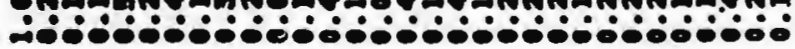

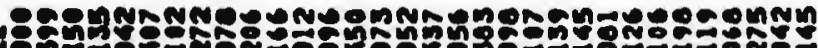

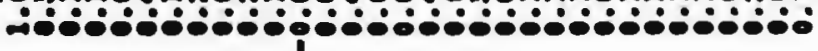
$\vdots$

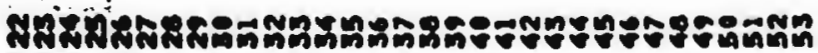
is
* $\quad$ :

\$

$\div$

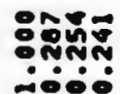

옹

$\%$

:คทำ

อิกีพกิ

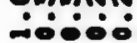

के

:ำำม

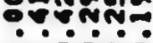

¿øio:

मू.

7

Bo-TNNN

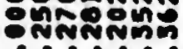
iดำ:

용

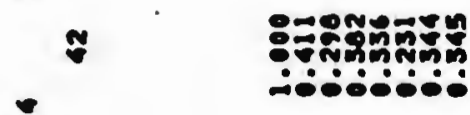

मे.

=

:

*

:

is

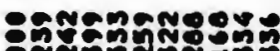

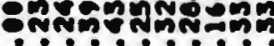
¿iobioió:

5

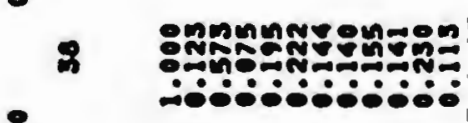

;

m

ฐ

:ำำำำํำำำ

รากำ

$\therefore 60 \div 0 \div 0 \div$

มี

म

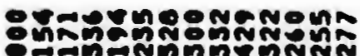

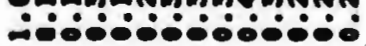

มิ

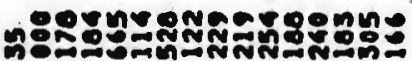
1.

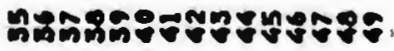

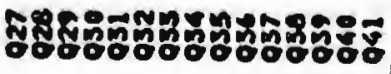


Appendix C (cont'd)

Table 10

Correlation Matrix

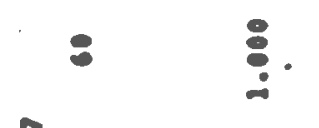

5

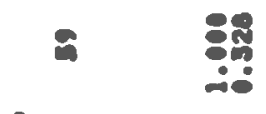

8

ㄷ. 8웅

8

$\because \approx$ 8숭

8

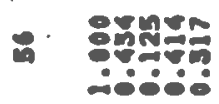

8

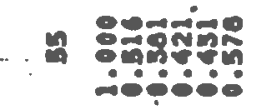

y

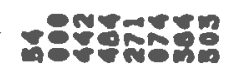

$\therefore-50.5$

3

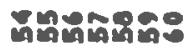

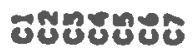


Bibliography

BMDP User's Digest (1990). Berkeley: University of California Press.

Breznitz, S., \& Goldberger, L. (1982). Stress research at a crossroads. In L. Goldberger \& S. Breznitz (Eds.), Handbook of stress: Theoretical and clinical aspects (pp. 3-6). New York: Free Press.

Chandler, L.A. (1984). Towards a stress assessment system for children. Paper presented at the convention of the National Association of School Psychologists, Philadelphia, PA.

Chandler, L.A., Million, M.E., \& Shermis, M.D. (1985). The incidence of stressful life events of elementary school-aged children. American Journal of Community Psychology, 13, 743-746.

Chimienti, G., Nasr, J.A., \& Khalifeh, I. (1989) Children's reactions to war-related stress: Affective symptoms and behavior problems. Social Psychiatry and Psychiatric Epidemiology, 24, 282-287.

Coddington, R. (1972). The significance of life events as etiologic factors in the diseases of children. Journal of Psychosomatic Research, 16, 7-18.

Coddington, R. (1972). The significance of life events as etiologic factors in the diseases of children. Journal of Psychosomatic Research, 16, 205-213.

Cohen, A., \& Dotan, J. (1976). Communication in the family as a function of stress during war and peace. Journal of Marriage and the Family, 141-148.

Colton, J.A. (1985). Childhood stress: Perceptions of children and professionals. Journal of Psychopathology and Behavioral Assessment, 7, 155-173.

Cronbach, L.J. (1951). Coefficient alpha and the internal structure of tests. Psychometrika, 16, 297-334.

Dobson, C.B., \& Metcalfe, R.J.A. (1993). Reliability and validity of the student stress inventory (sixth form version). British Journal of Educational Psychology, 53, 121-125.

Eisenberg, N., Pasternack, J., Cameron, E., \& Tryon, K. (1984). The relations of quantity and mode of pro social behavior to moral cognition and social style. Child 
Development, 55, 1479-1485.

Eisenberg, N., Shell, R., Pasternack, J., Lenin, R., Beller, J., \& Mathy, S. (1987). Prosocial development in middle childhood: A longitudinal study. Development Psychology, $23,712-718$.

Elwood, S.W. (1987). Stressor and response inventories for children. Psychological Reports, 60, 931-941.

Freud, A., \& Burlingham, D.T. (1944). War and children. International University Press.

Honig, A.S. (1986). Stress and coping in young children (Part 1) Young Children, 51-63.

Honig, A.S. (1986). Stress and coping in children (Part 2): Interpersonal family relationships. Young Children, 47-59.

Kaffman, M., \& Elizur, E. (1984). Children's bereavement reactions following death of the father. International Journal of Family Therapy, 6, 259-283.

Kanner, A.D., Coyne, J.C., Schaefer, C., \& Lazarus, R.S. (1981). Comparison of two modes of stress measurement: Daily hassles and uplifts versus major life events. Journal of Behavioral Medicine, $4,1-39$.

Karr, S.K. \& Johnson, P.L. (1987, March). Measuring children's stress: An evaluation of methods. Paper presented at the Annual Meeting of the National Association of School Psychologists.

Lazarus, R.S., DeLongis, A., Folkman, S., \& Gruen, R. (1985). Stress and adaptational outcomes: The problem of confounded measures. American Psychologist, 40, 770-779.

Lazarus, R.S., \& Launier, R. (1978). Stress-related transactions between person and environment. In L.A. Pervin \& M. Lewis (Eds.), Perspectives in interactional psychology (pp. 287-328). New York: Plenum Press.

Lemay, P. (1993). The impact of temperament and stress on academic achievement. Unpublished doctoral dissertation, University of Rhode Island, Kingston.

Lystad, M.H. (1984). Children's responses to disaster: Family implications. International Journal of Family Psychiatry, $\underline{5}$, 41-60. 
Maccoby, E.E., (1990). Gender and relationships: A developmental Account. American Psychologist, 45, 513-520.

Magnusson, D. (1982). Situational determinants of stress: An interactional perspective. In $\mathrm{L}$. Goldberger \& S. Breznitz (Eds.), Handbook of stress: Theoretical and clinical aspects pp.231-352. New York: Free Press.

Milgram, R. \& Milgram, N. (1976). The effect of the Yom Kippur war on anxiety level in Israeli children. The Journal of Psychology, 94, 107-113.

Myers-Walls, J.A., \& Fry-Miller, K.M. (1984). Nuclear War: Helping children overcome fears. Young Children, 39, 27-32.

Nagata, D.K. (1990). The Japanese American internment: Exploring the transgenerational consequences of traumatic stress. Journal of Traumatic Stress, 3, 47-69.

Omizo, M., Omizo, S., \& Suzuki, L. (1988). Children and stress: An exploratory study of stressors and symptoms. The School Counselor, 35, 267-274.

Phillips, B.N. (1978). School stress and anxiety. New York; Human Sciences Press.

Rosenheck, R. (1986). Impact of posttraumatic stress disorder of World War II on the next generation. Journal of Nervous and Mental Disease, 174, 319-327.

Rosenheck, R. (1985). Father-son relationships in malignant Post-Vietnam Stress Syndrome. American Journal of Social Psychiatry, $\underline{5}, 19-23$.

Rutter, M. (1988). Stress, coping and development: Some issues and questions. In N. Germenzy \& M. Rutter (Eds.). Handbook of stress: Theoretical and clinical aspects (pp. 515-528). New York: Free Press.

Selye, H. (1982). History and present status of the stress concept. In L. Goldberger \& S. Breznitz (Eds.), Handbook of stress: Theoretical and clinical aspects New York: Free Press.

Siegler, R., (1991). Children's thinking. Englewood Cliffs: Prentice Hall.

Thomas, R.M., (1992). Comparing theories of child development. California: Wadsworth Publishing Company. 
Yamamoto, K. (1979). Children's ratings of the stressfulness of experiences. Developmental Psychology, 15, 581-582.

Yamamoto, K. \& Byrnes, D. (1987). Primary children's ratings of the stressfulness of experiences. Journal of research in childhood education. ㄴ, 117-121.

Yamamoto, K. \& Davis, O.L. (1982). Views of Japanese and American Children concerning stressful experiences. Journal of Social Psychology, 116, 163-171.

Yamamoto, K. \& Felsenthal, H.M. (1982). Stressful experiences of children: Professional judgments. Psychological Reports, 50, 1087-1093.

Velicer, W. \& Jackson, D. (1990). Component analysis versus common factor analysis: Some issues in selecting an appropriate procedure. Multivariate Behavioral Research, $25,1-28$.

Zwick, W.R., \& Velicer, W.F. (1986). Comparison of five rules for determining the number of components to retain. Psychological Bulletin, 99, 432-442. 